\title{
EMINENT DOMAIN VALUATIONS IN AN AGE OF REDEVELOPMENT: INCIDENTAL LOSSES
}

Measurement of "just compensation" in condemnation actions has long plagued the field of eminent domain. ${ }^{1}$ The basic system of compensation-fair market value-was judicially developed in an effort to indemnify the condemnee for the property loss occasioned by condemnation. ${ }^{2}$ This formula, however, fails to assess what are often severe and costly losses sustained by owners and lessees of property. ${ }^{3}$ In theory, the market value standard is directed toward compensating the condemnee for the physical property loss suffered; thus it generally excludes recompense for incidental losses ${ }^{4}$-losses typified by damage

1. "[N]or shall private property be taken for public use, without just compensation." U.S. Const. amend. V. For the background to the adoption of this provision, see notes 15-19, 39 infra. All but two states have similar provisions in their constitutions. In those states, New Hampshire and North Carolina, this requirement has been read into the state constitutions by the courts. See Petition of Mount Washington Road Co., 35 N.H. 134, 142 (1857); Opinion of the Justices, 66 N.H. 629, 33 Atl. 1076 (1891); Staton v. Norfolk \& C.R.R., 111 N.C. 278, 16 S.E. 181 (1892).

2. The market measure of value in eminent domain is the price at which a willing seller would have sold and a willing purchaser would have bought the condemned property on a free and open market. Westchester County Park Comm'n v. United States, 143 F.2d 68S, 692 (2d Cir. 1944). See also United States v. Miller, 317 U.S. 369, 374-75 (1943). At times, "the application of this concept involves, at best, a guess by informed persons." Id. at 375 .

3. In condemnation proceedings, the special adaptability of the property to the owner is disregarded in compensating the condemnee. United States v. Miller, 317 U.S. 369, 375 (1943). For the effect of this policy see Grutzner, Housing Projects Make Bitter D.P.'s, N.Y. Times, March 18, 1957, p. 29, col. 1. See also Hearings Before the House Committec on Banking and Currency on H.R. 10157, 84th Cong., 2d Sess. 69, 337 (1956); House Committee on Banking and Currency, Subcommittee on Housing, Slum Clearance and Urban Renewal, H.R. Rer. No. 1, 84th Cong., 2d Sess. 8-9 (1956).

4. "The sovereign ordinarily takes the fee. The rule in such a case is that compensation for that interest does not include future loss of profits, the expense of moving removable fixtures and personal property from the premises, the loss of good-will which inheres in the location of the land, or other like consequential losses which would ensue the sale of the property to someone other than the sovereign. No doubt all these elements would be considered by an owner in determining whether, and at what price, to sell. No doubt, therefore, if the owner is to be made whole for the loss consequent on the sovereign's seizure of his property, these elements should properly be considered. But the courts have generally held that they are not to be reckoned as part of the compensation for the fee taken by the Government." United States v. General Motors Corp., 323 U.S. 373, 379 (1945).

See, generally, 1 Orget, Valuation UnDer EariNent Domain $\$$ 66-80 (2d ed. 1953) (hereinafter cited as Orger). See also 1 Bongright, Valuation of Property 411 (1937) (hereinafter cited as BoNBRIGHT).

While the courts often refer to "incidental losses" as "consequential losses," the latter term is used more appropriately in those instances in which the condemnor takes only part of the condemnee's real estate. The term "incidental losses" is used herein to describe nonphysical property losses to the condemnee, usually occurring when the entire fee is taken. See note 96 infra. 
to or destruction of good will, ${ }^{\mathbf{5}}$ expenses incurred in moving to a new location ${ }^{6}$ and profits lost because of business interruption or inability to relocate. ${ }^{7}$ In denying these losses, courts have recognized that such action constitutes a

5. Banner Milling Co. v. New York, 240 N.Y. 533, 539-40, 148 N.E. 668,670 (1925); Burdick v. New York, 276 App. Div. 1052, 95 N.Y.S.2d 869 (4th Dep't 1950), aff'd, 302 N.Y. 670, 98 N.E.2d 478 (1951); Oakland v. Pacific Coast Lumber and Mill Co., 171 Cal. 392, 398, 153 Pac. 705, 707 (1915) ; In re Jeffries Homes Housing Project, 306 Mich. 638, 651, 11 N.W.2d 272, 276 (1943); Newark v. Cook, 99 N.J. Eq. 527, 537-3S, 133 Atl. 875,879 (Ch. 1926), aff'd, 100 N.J. Eq. 584, 135 Atl. 915 (Ct. Err. \& App. 1927) ; Reeves v. Dallas, 195 S.W.2d 575, 581-83 (Tex. Civ. App. 1946). See also 1 Orger $\$ 75$ n.43; 2 Lewis, Eminent Dodrain $\$ 727$ (3d ed. 1909); 2 Nichols, Eminent Domain 113 n.30 (3d ed., Sackman \& Van Brunt 1950) (hereinafter cited as Nichols). But see Grand Rapids \& I.R.R. v. Weiden, 70 Mich. 390, 395, 38 N.W. 294, 295-96 (188s).

Often courts use "good will" and "going concern" interchangeably. See, e.g., Banner Milling Co., supra at 543, 148 N.E. at 671. See also note 61 infra.

6. United States v. Westinghouse Elec. \& Mffg. Co., 339 U.S. 261, 264 (1950); United States v. Petty Motor Co., 327 U.S. 372, 377-78 (1946) ; United States v. Inlots, 26 Fed. Cas. No. 15441, at 489 (C.C.S.D. Ohio 1873); Highway Comm'n v. Superbilt Mfg. Co., 204 Ore. 393, 426, 281 P.2d 707, 722 (1955) ; Springfield S.W. Ry. v. Schweitzer, 173 Mo. App. 650, 158 S.W. 1058 (1913) ; Emery v. Boston Terminal Co., 178 Mass. $172,186,59$ N.E. 763,766 (1901). See also United States v. Building Known as 651 Brannan Street, 55 F. Supp. 667, 669 (N.D. Cal. 1944); 1 OrGes $\S 69$ n.3. The cases that have allowed recovery for moving costs differ in their reasoning. Some courts include them as an element of market value while others have allowed recovery as a separate item of damage. Harvey Textile Co. v. Hill, 135 Conn. 686, 67 A.2d 851 (1949) (included within market value); West Side Elevated R.R. v. Siegel, 161 Ill. 638, 44 N.E. 276 (1896) (separate item of damage) ; In re Widening of Gratiot Avenue, 294 Mich. 569, 293 N.W. 755 (1910) (included "as an element of damages"); Richmond v. Williams, 114 Va. 698, 703, 77 S.E. 492, 494 (1913) (separate item of damage) ; Blincoe v. Choctaw, O. \& W.R.R., 16 Okla. 286, 296, 83 Pac. 903, 907 (1905) (same). See also Patterson v. Boston, 40 Mass. (23 Pick.) 425, 430 (1840); United States v. General Motors Corp., 323 U.S. 373 (1945), discussed at note 78 infra.

7. Mitchell v. United States, 267 U.S. 341, 345 (1925) ; United States v. 25.4 Acres of Land, 71 F. Supp. 255, 260 (E.D.N.Y. 1947) ; Application of Westchester County, 204 Misc. 1031, 1037-38, 127 N.Y.S.2d 24, 31 (Sup. Ct. 1953) ; Katonah Lumber, Coal \& Feed Co. v. State, 194 Misc. 311, 314-15, 86 N.Y.S.2d 696, 700 (Ct. C. 1949); Herdon v. Housing Authority, 261 S.W.2d 221, 223 (Tex. Civ. App. 1953) ; Hunter's Adm'r v. Chesapeake \& O. Ry., 107 Va. 158, 166, 59 S.E. 415, 418 (1907) ; Becker v. Philadelphia \& R.T.R.R., 177 Pa. 252, 258, 35 Atl. 617, 620 (1896). But see Patterson v. Boston, 40 Mass. (23 Pick.) 425, 430 (1840). See, generally, 1 ORGEs $\S 72$ n.32.

As a general rule, evidence of profits to show the value of the property is inadmissible, as is such evidence to establish the loss to the owner of profits because of interruption in his business or inability to relocate. Department of Pub. Works v. Lambert, 411. I1l. 183, 194, 103 N.E.2d 356, 362 (1952) ; State v. Darnall, 129 W. Va. 159, 161, 38 S.E.2d 663, 665 (1946) ; cf. In re Cross-Bronx Expressway, 195 Misc. 842, 852-55, 82 N.Y.S.2d 55, 68-70 (Sup. Ct. 1948). Nonetheless, for numerous reasons, chiefly because calculating a market value without resorting to profit figures would often be impossible, courts frequently permit profit data to be introduced as evidence of the market value of the property. See 1 OrGer §§ 155-64. See also State Roads Comm'n v. Novosel, 203 Md. 619, 623-25, 102 A.2d 563, 565 (1954).

Among other incidental costs condemnees must bear are costs of purchasing and installing new fixtures in the new location and costs incident to changes in business stationery, telephone service, advertising and signs. 
derogation of the indemnity principle and makes "harsh" law. 8 Nonetheless, the practice continues, justified by reasoning which, upon critical examination, reflects dubious wisdom and logic.

Today, more than ever before, the denial of incidental losses assumes major importance in the area of eminent domain. ${ }^{9}$ The scope and nature of contemporary takings have aggravated the injury which results from condemnation. Initially, the great number of takings inflicts losses on an ever-increasing multitude of people; ;0 $^{10}$ such projects as large scale federal and state road building and mushrooming urban renewal leave few segments of the nation directly unaffected. ${ }^{11}$ These programs also involve taking of improved commercial and industrial property where incidental losses are necessarily more

8. United States v. General Motors Corp., 323 U.S. 373, 382 (1945) ("the consequences often are harsh"); General Motors Corp. v. United States, 140 F.2d 873, 874 (7th Cir. 1944) ("hard law"); Newark v. Cook, 99 N.J. Eq. 527, 538, 133 Atl. 875, 879 (Ch. 1926) ("That is the law. It works hardships.") ; Oakland v. Pacific Coast Lumber and Mill Co., 171 Cal. 392, 398, 153 Pac. 705, 707 (1915) ("We are not to be understood as saying that this should not be the law when we do say that it is not our law.").

9. The staggering proportions of eminent domain at present are seen in the fact that at the end of 1956 under the urban renewal program 433 slum clearance projects were in execution across the nation. Housing and Home Finance Agency, Urban Renewal Administration, Urban Renewal Project Characteristics 6 (1956). In the past five years, about 400 miles of throughways, "outer" and "inner" belts have been constructed by the nation's twenty-five largest cities. Can the Big Cities Come Back?, U.S. News and World Report, July 19, 1957, p. 73. The federal highway program will spend over thirty-three billion dollars in the next fifteen years, half that sum devoted to urban road building. Ingraham, Autos Rule and Frustrate Life in the Urban Region, N.Y. Times, Jan. 28,1957 , p. 16 , col. 5 . At the same time, local and state governments are continuing their own expanded road programs. New parking facilities in 1957 are expected to cost more than half a billion dollars. U.S. News and World Report, supra. In addition, extensive takings for public housing projects, public markets, hospitals, schools, parks, etc. are being brought about by the significant population growth in urban and suburban communities.

10. The effect of the increased use of eminent domain is indicated in a recent house committee report: "The subcommittee has available no quantitative estimates of the number of displaced families, but it is significant to point out that in New York City alone it was estimated that some 67,000 families face displacement during the period 195557. This contrasts with an approximate family displacement of 7,700 annually in the 7-year period 1946 to 1953." House Committee on Banking and Currency, Subcommittee on Housing, Slum Clearance and Urban Renewal, H.R. REP. No. 1, 84th Cong., 2d Sess. 7 (1956). In the 216 urban renewal projects designated as being in the "well-advanced" stage at the end of 1955, more than 100,000 families had been or were slated to be relocated because their homes were condemned. Housing \& Hoxise Finance Agency Ann. Rep. 406 (1956).

11. The broad impact of modern condemnation programs is illustrated by the federal highway program which alone is expected to require the taking of a million acres of land. Grutzner, Rise of the Urban Region: A Study of New Way of Life, N.Y. Times, Jan. $27,1957, \S 1$, p. 72 , col. 5. Of the 265 communities in the nation that had urban renewal projects in the advanced stage by January 1957, one fourth were cities of less than 10,000 population. Housing and Honse Finance Agency, Urban Renewal Administration, Urban Renewal Project Characteristics 6 (1956). 
prevalent and serious. ${ }^{12}$ Furthermore, present takings, by tending to encompass large areas of contiguous property, make prompt relocation to mitigate losses considerably more difficult. And, as popular indignation due to the denial of these losses may seriously impede beneficial redevelopment programs, ${ }^{13}$ the workings of the market value formula take on an importance apart from the individual rights affected.

In light of the admitted inequities of the market value formula ${ }^{14}$ and because of the increasing significance of governmental redevelopment programs, reexamination of the present system of compensation in eminent domain, particularly as it applies to incidental damages, is necessary. This Comment will first examine the history of the interpretation of "just compensation," its relation to the market value formula and the prevailing arguments and logic for the denial of incidental damages. It will then describe the serious effect brought about by the failure to compensate for these losses and analyze the areas in which the market value test has been by-passed to avoid the restrictions inherent in that standard. The Comment will finally consider these problems as they apply today, with emphasis on the market value formula in relation to modern redevelopment programs and especially urban renewal, a most significant source of present-day takings.

12. The hardship produced by present-day governmental programs involving eminent domain has led to the introduction of bills in various legislatures to compensate condemnees for incidental losses. As an example, one such measure, Conn. Sen. Bill No. 610, Feb. 1, 1955, declared in its statement of purpose: "The present statutes relating to the methods of appraising damages when land is taken for highway purposes were designed primarily for the appraisal of rural and residential property. They are recognized as being inadequate when the property to be taken is of an industrial or business nature." This measure was not approved by the legislature. See Conn. Sen. Bill No. 362, Jan. 23, 1957. See also note 113 infra.

The extent to which such a program as urban renewal affects commercial concerns can be seen by statistics contained in a report to the New Haven Redevelopment Agency. In the first of a number of urban redevelopment projects to be completed in that city, 312 businesses of various kinds in one area were displaced by condemnation. Of these, $50 \%$ sought the assistance of the Redevelopment Agency in an effort to relocate their businesses. (The 109 businessmen who had been interviewed and desired assistance fell into the following categories: retail-42; wholesale-24; service-28; industrial-15.) New Haven Redevelopainent Agency, Report of Business Relocation Office for the Pertod March 1-June 30, 1956.

13. The failure to allow for incidental damages has led to frequent public denunciation of redevelopment programs and has aligned important and numerous segments of the population against these programs. See articles and letters to the editor in the N.Y. Times expressing this indignation: Aug. 28, 1956, p. 29, col. 1; Feb. 23, 1957, p. 19, col. 1; March 1S, 1957 , p. 29, col. 1. See also New Haven Register, Aug. 30, 1957, p. 1, col. 1. At times this hostility on the part of those adversely affected by redevelopment programs produces threats to exert political pressure against officeholders in order to block the progress of such programs. N.Y. Times, Sept. 8, 1956, p. 19, col. 5; Sept. 9, 1956, § 1, p. 81, col. 1; Sept. 12, 1957, p. 1, col. 1.

14. The present "rigid rules" for measuring compensation were summarized by one court which stated, "Equitable principles, no matter how well founded, are rendered inoperative in a condemnation proceeding." United States v. 257.654 Acres of Land, 72 F. Supp. 903, 914 (D.C. Hawaii 1947). 


\section{The Market Value Standard: An Historical Analysis}

Although the power of eminent domain was utilized early in this country's history, takings seldom entailed incidental losses. ${ }^{15}$ In fact, while the obligation to make compensation had been incorporated into constitutions of the federal government and many states, ${ }^{10}$ payment of any compensation was rare since loss resulting from the average taking was slight. ${ }^{17}$ The takings which did occur generally involved unclaimed and unimproved private property, or land governmentally owned. ${ }^{18}$ Takings did not assume significant proportions until well into the nineteenth century, when railroad construction became an important factor in American life. ${ }^{19}$ Thus, incidental losses, which usually follow condemnation of improved commercial and industrial property, were not appreciable factors when the formulae for compensation were developed by the courts. The absence of these considerations resulted in the establishment of theories of compensation which did not include payment for incidental losses, and accounted for the lack of popular insistence that such damages were part of the "just compensation" guarantee of the Fifth Amendment.

"Compulsory acquisition" in England during the same period illustrates the effect which the different degrees of urban and industrial development in the two countries had in producing divergent doctrines of compensation. "Expropriation" in that country was not extensively utilized until the first half of the nineteenth century, about fifty years prior to any significant condemnation

15. See Comment, The Public Use Linitation on Eminent Donain: An Advance Requiem, 58 Yale L.J. 599, 600 (1949) ; McCoRMICK, DaMages 541 n.28 (1935) (hereinafter cited as MCCoRAICK). Roads were the primary object of eminent domain, and, because the country at the time of its settlement was wholly unimproved, land could be acquired without need to recompense. The first provision for road construction appeared in Massachusetts in 1639. Authority was given to lay out highways "provided always it occasioned not the pulling down of any man's house, or laying open any garden or orchard." 1 Nichols 39-40.

16. See id. at 50-55; Dodge, Acquisition of Land by Eminent Domain, in LAND UsE Controls, X : 7-8 (Beuscher ed.). States that did not have written provisions regarding compensation often resorted to "natural" or "higher" law. Support was found for this position not only in the writings of Grotius and others but the Ninth Amendment was also raised to support "vested property rights." See Cormack, Legal Concepts in Cases of Eninent Domain, 41. YALE L.J. 221, 222 (1931) ; Grant, The "Higher Laze" Backgrotnd of the Law of Eminent Domain, 6 WIs. L. REv. 67, 70-71 (1931). See also Sinnickson v. Johnson, 17 N.J.L. 129, 153 (Sup. Ct. 1839).

17. See Comment, The Public Use Limitation on Eminent Domain: An Advance Requiem, 58 YALE L.J. 599, 600 \& n.6 (1949).

18. 1 Nichols 39. Apparently a marked relationship existed between population concentration and compensation. Where highways had to be constructed in urban areas, compensation for land became a prerequisite; in less developed areas, highway building was not considered a deprivation of private property rights. See id. at 40-43.

19. Comment, 1 VILL. L. Rev. 105 (1956); see Comment, The Public Use Limitation on Eninent Domain: An Advance Requiem, 58 Y ALE L.J. 599, 601-02 (1949).

20. The terms "compulsory acquisition" and "expropriation," see text at note 21 infra, are both counterparts of the term condemnation as used in this country. 
activity in the United States. ${ }^{21}$ In both nations, the necessity for extensive taking was ushered in by railroad development. ${ }^{22}$ But in England the acquisitions involved highly developed industrial and commercial areas, and the taking of property wrought considerably more damage to the condemnee than resulted from takings in this country. ${ }^{23}$ Moreover, since compulsory acquisition was used primarily for the benefit of profit-making railroads, both the courts and the public were more sympathetic in viewing the treatment to be afforded the condemnee. Not only did the English courts grant awards for incidental damages by adopting the vague standard "value to the owner," they initiated the policy of increasing the award by ten per cent to compensate the condemnee for general inconvenience. ${ }^{24}$ And while in recent years recognition that a compensation formula as nebulous as "value to owner" gives too little guidance and produces exaggerated awards has led to modification of the English standard, English courts continue to compensate for incidental losses. ${ }^{25}$

When first presented with cases involving substantial incidental damages, American courts denied recovery for these losses on the ground that the rights of property did not inhere in such intangible interests. ${ }^{26}$ Soon, however, the courts adapted their arguments in eminent domain to the expanded concept of property existing in other areas of the law and recognized that such losses did in fact involve property interests. ${ }^{27}$ Nevertheless, they continued to disallow

21. See Ministry of Reconstruction, Second Report of the Committee Dealing with the Law and Practice Relating to the Acouisition and Valuation of Land For Public Purposes 8 (Scott Rep. 1918). See also 2 Orgei $\$ 251$.

22. Ibid. See also notes 15,19 supra.

23. The situation in England has been labelled directly opposite to that which existed in the United States. See 1 Nichols 39.

24. See note 21 supra. For examples of incidental damages see Cooper v. Metropolitan Bd. of Works, 25 Ch. D. 472 (C.A. 1883) (plaintiff-tailor entitled to good will compensation despite the fact that his condemned premises were mortgaged) ; Senior v. Metropolitan Ry., 2 H. \& C. 258, 159 Eng. Rep. 107 (Ex. 1863) (plaintiff entitled to damages for loss of trade or good will resulting from railway obstructing highway on which plaintiff had his shop).

25. See $9 \& 10$ Geo. 5, c. 57, \& 2 (1919), containing six rules for compensation. Rule 2, which provides for compensation for land based on what a willing seller might be expected to realize on an open market, does not by the inclusion of Rule 6 affect the compensation the condemnee receives because of "disturbance or any other matter not directly based on the value of land." W. Rought, Ltd. v. West Suffolk County Council, [1955] 2 All E.R. 337 (C.A.) ; cf. Horn v. Sunderland Corp., [1941] 1 All E.R. 480 (C.A.). However, Canadian courts apparently apply not only the value to the owner criterion but also grant $10 \%$ extra for inconvenience to the condemnee. See Pawson v. City of Sudbury, [1953] Ont. 988. But see 1 Orgel $\$ 45$.

26. See, e.g., Commissioners of Homochitto River v. Withers, 29 Miss. 21, 32 (1855) (property must be of a "tangible nature, capable of being had in possession and transmitted to another, as houses, lands, and chattels"). Cf. Sullivan v. Associated Billposters and Distributors, 6 F.2d 1000, 1011 ( $2 \mathrm{~d}$ Cir. 1925), where the court asserts that business is not property in a constitutional sense. See also 1 Orger $\$ 2$.

27. Priolo v. Dallas, 234 S.W.2d 1014 (Tex. Civ. App. 1950), rev'd on other grounds, 150 Tex. 423, 242 S.W.2d 176 (1951) ; Reeves v. Dallas, 195 S.W.2d 575 (Tex. Civ. App. 1946). Cf. United States v. General Motors Corp., 323 U.S. 373, 377-78 (1945), 
recovery; the now traditional rationale for denying incidental losses was advanced: these interests are not property rights vis-a-vis the government. ${ }^{28}$ Reasoning that government need only pay for that which it "takes," the courts considered as a corollary that taking involved a taking over of tangible interests. ${ }^{29}$ Since government when condemning property seldom takes over anything but the realty, it need only pay for what it has gained rather than for what the condemnee has lost. ${ }^{30}$ This argument has been buttressed and given constitutional foundation by the assertion that the right to just compensation is a property right and not personal; in effect, the distinction results in the scope of taking being restricted to the property involved. The classic statement of this in rem - in personam dichotomy was advanced by Justice Brewer in Monongahela Nav. Co. v. United States:

"And this just compensation, it will be noticed, is for the property and not the owner. Every other clause in the Fifth Amendment is personal. 'No person shall be held to answer for a capital, or otherwise infamous crime,' etc. Instead of continuing that form of statement, and saying that no person shall be deprived of his property without just compensation, the personal element is left out, and the 'just compensation' is to be a full equivalent of the property taken."31

where the Court discussed two ways of using the term "property." On the one hand is the untechnical sense of the physical thing; "more accurate," the Court felt, is the "interest in the thing in question" or a bundle of rights that need not be physical. Compare Mitchell v. United States, 267 U.S. 341, 345 (1925) ; Sawyer v. Commonwealth, 182 Mass. 245, 247, 65 N.E. 52, 53 (1902). See alsa 1 Orget $\$ 2$; McCormick 537-38.

28. Kratovil \& Harrison, Eminent Domain-Policy and Concept, 42 CaLIF. L. REv. 596, 603-04 (1954); 2 Nichols 288. But see Priolo v. Dallas, supra note 27, where the court granted lost profits to the condemnee when part of his business' parking space was taken. The court stated: "A going business is property. ... Our [state] Constitution ... states: 'No person's propcrty shall be taken ...., etc. The Legislature could not and did not limit the compensation in this case to the land alone, either by statute or in the City Charter, to less than the Constitution provided for." On appeal, the case was reversed, mainly because lost profits had been considered as a separate item of damage, and the higher court felt that they should only be considered as affecting market value. Where the entire fee is taken, lost profits are not usually admitted as an element of market value. See note 99 infra.

29. See Cormack, supra note 16, at 225; Kratovil \& Harrison, supra note 28, at 599.

30. See Mitchell v. United States, 267 U.S. 341, 345 (1925). In this case, the condemnee's canning business was destroyed due to the inability to re-establish elsewhere. Brandeis, J., stated: "There is no finding as a fact that the Government took the business, or that what it did was intended as a taking. If the business was destroyed, the destruction was an unintended incident of the taking of land. There can be no recovery under the Tucker Act if the intention to take is lacking." See also United States ex rel. TVA v. Powelson, 319 U.S. 266, 282 (1943) ("the sovereign must pay only for what it takes, not for opportunities which the owner may lose") ; In re Jeffries Home Housing Project, 306 Mich. 638, 651, 11 N.W.2d 272, 276 (1943) (good will not compensable where the business is not taken) ; Banner Milling Co. v. New York, 240 N.Y. 533, 539-40, 148 N.E. 668,670 (1925) (same).

31. $14 S$ U.S. 312, 326 (1S93). Despite this language, the Court granted the company compensation for the loss of its franchise to collect tolls, asserting that the federal government had put itself in a position to collect tolls. Id. at 337-38. Thus the Court was able to 
Whatever may be said for the logic and wisdom of this interpretation, ${ }^{32}$ the Monongahela rationale soon set the pattern for both federal and state decisions. ${ }^{33}$ Thus evolved the compensation test universally applied in America today-market value of the property taken.

Presented with the implications of this doctrine, various state legislatures sought to limit its ramifications in other areas where property was damaged or destroyed through the agency of government instrumentalities. Because the Monongahela logic had been interpreted to encompass real property which was damaged although not physically entered upon or condemned, a number of states altered their constitutions to permit compensation in these special

avoid the distinction between taking over and destruction. See United States v. Petty Motor Co., 327 U.S. 372, 377 (1946); Eagle Lake Improvement Co. v. United States, 160 F.2d 182, 184 (5th Cir. 1947); United States v. 257.654 Acres of Land, 72 F. Supp. 903, 914-15 (D.C. Hawaii 1947) ; Grand River Dam Authority v. Gray, 192 Okla. 547, 54S-49, 138 P.2d 100, 102 (1943). See also cases cited 2 Lewis, ExIINENT Donsain $\$ 512$ (3d ed. 1909). Interestingly, Mr. Justice Brewer, in an address to the graduating class of the Yale Law School in 1891, expressed concern over insuring just compensation to the individual. He did, however, somewhat foreshadow the view he expressed two years later in Monongahela: "[T] here remains to the individual a sacred and indestructible right of compensation. If, for the public interests and at the public demands, he sacrifices his time, his labor or his property, or any value therein, he has a right to demand and must receive at the hands of the public compensation therefor." BREWER, Protection to Prrvate Property frons Public Attack 21 (Yale Law Library Pam. No. 42).

32. A number of judicial protests were raised against the practice of using such reasoning to deny compensation for nonphysical losses. See Patterson v. Boston, 40 Mass. (23 Pick.) 425 (1839). Compare Pumpelly v. Green Bay Co., S0 U.S. 166 (1871); Eaton v. B.C. \& M.R.R., 51 N.H. 504, 511 (1872) ; Thompson v. The Androscoggin River Improvement Co., 54 N.H. 545, 551 (1874), where courts objected to the restricted meaning of "taking." See also Sedgwrck, Statutory and Constitutional Law 524 (1857). See, generally, Cormack, supra note 16.

Among the leading writers opposing the Monongehela approach to "taking" are Cormack and Lewis. Ibid.; 1 Lewis, Eninent Donarn 62 (3d ed. 1909). Among those writers upholding the restrictive concept of "taking" are Nichols and Dolan. See 2 Nichols 288; Dolan, "Iust Compensation" and the General Motors Case, 31 VA. L. Rev. 539,549 (1945). Nichols bases his position on an adherence to precedent, adding that regardless of the logic of the Eaton case, supra, it came "too late to stand on its merits as an interpretation of the constitution." Dolan apparently holds that if incidental losses are to be granted it is the responsibility of the legislatures; he adds, "'just compensation' does not include damages." But of. W. Rought, Ltd. v. West Suffolk County Council [1955] 2 All E.R. 337, 342 (C.A.): "What a payer has to pay by way of compensation is . . . a sum so as to put, so far as money can do it, the owner in the same position as if his land had not been taken from him; and this ... is exactly the same measure as the measure of damages applied to the case of a man liable to pay compensation for breach of contract or, for that matter (where there is no question of punitive damages) in tort."

33. "The decision as to whether compensation should be made generally has been reached, however, upon purely legalistic grounds with a physical conception of the eminent domain process in mind." Cormack, supra note 16, at 257-58. See 2 NICHoLs 285. Recent cases explicitly upholding the in rem approach are State Highway Comm'n v. Burk, 200 Ore. 211, 244-45, 265 P.2d 783, 799 (1954); United States v. Building Known as 651 Brannan Street, 55 F. Supp. 667, 670 (N.D. Cal. 1944). 
instances. ${ }^{34}$ The courts also sought to protect individual property rights against the government. But they did so, not by making just compensation the battleground as had been the case in England, but by narrowing the concept of "public use"- the raison d'être for government takings. ${ }^{35}$ In the face of popular acceptance and approval of public enterprises, however, the courts' restrictive attitude was short-lived. ${ }^{36}$ The conflict in eminent domain "between the people's interest in public projects and the principle of indemnity to the landowner" was resolved in favor of a broad public use doctrine and a restrictive definition of compensation. ${ }^{37}$

Denial of incidental losses based upon the Monongahela rationale is subject to serious criticism. Justice Brewer's analysis of the Fifth Amendment, even if reasonable, need not apply to state constitutions. Many state constitutions direct that no "person" be denied just compensation..$^{38}$ Moreover, Justice

34. Lenhoff, Development of the Concept of Eminent Domain, 42 CoLUM. L. REv. 596, 610 (1942); Dodge, Acquisition of Land in Eminent Domain, in LANd Use ConTrols $\mathrm{X}: 10$ (Beuscher ed.). For a listing of the states that have "taking and damaged" provisions, see MicCorarxck 536.

That these provisions have generally been interpreted to exclude incidental losses in cases of physical taking, see United States v. General Motors Corp., 323 U.S. 373, 380 (1945); Oakland v. Pacific Coast Lumber and Mill Co., 171 Cal. 392, 398, 153 Pac. 705, 707 (1915) ; Reeves v. Dallas, 195 S.W.2d 575, 583-84 (Tex. Civ. App. 1946); 1 ORGEL $\S 78$. However, at least one state, Indiana, appears to have interpreted its statute to allow compensation for incidental losses to the business when the real property is taken by eminent domain. In Indiana v. Stabb, 226 Ind. 319, 79 N.E.2d 392 (1948), the court interpreted IND. ANN. STAT. $\S 3-1706$ (Burns Supp. 1955) to encompass within the measure of compensation damages incurred because of lost profits or other losses to the business. In so deciding this question, the Indiana court overruled all previous holdings which indicated that such damages were not compensable. Indiana v. Stabb, supra at 324,79 N.E.2d at 395 . Furthermore, the court apparently did not limit its holding to permit such compensation for incidental losses to cases involving partial takings. In partial taking situations, some courts make an exception to the general rule prohibiting compensation for these losses. See note 99 infra.

35. For the adoption and evolution of the "narrow" view of public use, see Nichols, The Meaning of Public Use in the Law of Eminent Domain, 20 B.U.L. REv. 615 (1940); Comment, The Public Use Limitation on Eminent Domain: An Advance Requiem, 58 YaLE L.J. 599, 602 (1949). Apparently, the courts also sought to exert their supremacy over the legislature by limiting the latter's power in the field of eminent domain. Ibid.; see Bloodgood v. Mohawk \& H.R.R., 18 Wend. $* 9, * 60, * 62$ (N.Y. 1837) (concurring opinion).

36. See note 35 supra; Cormack, supra note 16, at 226. The "public use" concept was, at the turn of the century, given a broad interpretation. In discarding the "narrow" view of public use, the Idaho court stated, "it is enough if the taking tends to enlarge resources, increase the industrial energies and promote the productive power of any considerable part of the inhabitants of a section of the state, or leads to the growth of towns and the creation of new channels for the employment of private capital and labor, as such results indirectly contribute to the general prosperity of the whole community." Potlatch Lumber Co. v. Peterson, 12 Idaho 769, 785, 88 Pac. 426, 431 (1906).

37. United States ex rel. TVA v. Powelson, 319 U.S. 266, 280 (1943).

38. See, c.g., MAss. Consr. art. X: "And whenever the public exigencies require that the property of any individual should be appropriated to public uses, he shall receive a reasonable compensation therefor." $C f$. the language in other state constitutions: ConN. 
Brewer's assertion is itself a dubious constitutional pronouncement. The Bill of Rights was incorporated into the Constitution as a deliberate means of guaranteeing the individual various rights. ${ }^{39}$ As Justice Holmes observed, constitutions deal "with persons, not with tracts of land." 40 The Monongahela pronouncement, stressing a restrictive meaning of property, excludes an examination of the phrase "just compensation," which is at least equally important in ascertaining the Fifth Amendment's command.41 Modern day adherents of the Monongahela position continue to base their interpretation of the Fifth Amendment on conditions which existed in the nineteenth century.42 Yet the peculiar factors surrounding that restrictive policy interpretation, which may have supplied some justification for the original doctrine, no longer exist. Monongahela remains an outdated common-law concept of property, developed in the absence of conditions revealing its harshness.

Aware of the doctrine's shortcomings and feeling discomfort in resting

Const. art. I, $\S 11$; CAL. Const. art. I, $\$ 14$; DeL. Const. art. I, $\S 18$; IND. Const. art. I, $\S 21$; Ky. Const. $\S 13$; Md. Const. art. III, $\S 40$; OhIo Const. art. I, $\S 19$; Ore. Const. art. I, § 18; Tenn. Const. art. I, § 21 ; Tex. Const. art. I, § 17; Vt. Const. c. I, art. 2.

Moreover, a considerable number of states have the additional provision in their constitutions that requires compensation for "damage" to property as well as for property actually "taken." See McCoRMICK $\mathbf{5 3 6}$ for listing. But these "damage" provisions have not been interpreted to allow for incidental losses. See note 34 supra and accompanying text.

39. The Bill of Rights was added to the Constitution to protect explicitly the rights of both persons and property against the undue exertion of governmental power. See CoNSTITUTION OF THE UNITED STATES 750 (Corwin ed. 1952). The language of the Ordinance of 1787, adopted while the Constitutional Convention was engaged in drafting the Federal Constitution, suggests that compensation under eminent domain was thought of as a personal right: "No man shall be deprived of his liberty or property, but by the judgment of his peers or the law of the land; and, should the public exigencies make it necessary, for the common preservation, to take any person's property, or to demand his particular services, full compensation shall be made for the same." Ordinance of 1787 for the Northwest Territory, art. 2.

The compensation limitation on the sovereign's power of eminent domain was incorporated into only two state constitutions prior to the adoption of the Federal Constitution. But most states had statutory provisions that were precursors of later formal constitutional restrictions in eminent domain. These provisions were derived from article 39 of the Magna Charta, the language of which was clearly aimed at protecting personal rights ("That no freeman ought to be taken, or imprisoned, or disseized of his freehold ...."). See Dodge, Acquisition of Land in Eminent Domain, in LaNd UsE CoNTrols X: 7, 9 (Beuscher ed.).

40. Boston Chamber of Commerce v. Boston, 217 U.S. 189, 195 (1910).

41. The Florida court, in allowing compensation for business losses in a right of way taking, recognized that the general rule is to disallow such losses. But the court stated that the state statute, enacted pursuant to the state constitution, "requires that full compensation must be made. Full compensation means nothing less than payment for that which the property owner is being deprived of." Meyers v. Daytona Beach, 158 Fla. 859, 862, 30 So. $2 \mathrm{~d} 354,355$ (1947). In general, no distinction has been made elsewhere between "just," "adequate" or "full" compensation. The Florida holding, however, would seem to be limited to partial takings, despite the broad language of the court. See note 99 infra.

42. That the constitutional founders did not contemplate the mass takings which now commonly cause incidental damages is fairly apparent. See Nichols, The Meaning of Public Use in the Law of Eminent Domain, 20 B.U.L. REv. 615, 617 (1940); note 12 supra. 
denial of incidental losses on "property" grounds, courts have advanced a second major argument for denying recovery; they have labelled these losses speculative. Repeatedly, particularly in recent years, courts have warned that compensation for losses which the market standard excludes would result in unfounded and exaggerated awards. ${ }^{43}$ Basing their reasoning on the belief that personal losses are too difficult, remote and uncertain to measure accurately, courts assume and often explicitly state that the market value formula is objective and that its expansion to compensate for any subsidiary losses would completely undermine its inherent accuracy. ${ }^{44}$

But measurement of incidental losses would not be as speculative as the courts have asserted. True, accountants and economists differ widely with regard to measurement of good will. ${ }^{45}$ Moving costs, moreover, are partially subject to the condemnee's peculiar taste in relocating. ${ }^{46}$. And compensating for lost profits would raise difficulties of evaluation as well as insure the condemnee for expectant earnings. ${ }^{\mathbf{4 7}}$ Nonetheless, courts have resolved identical problems which have arisen in private suits within the field of contract and tort, in addition to actions involving taxation. ${ }^{48}$ More significant, courts have

43. See United States v. General Motors Corp., 323 U.S. 373, 385 (1945) (Douglas, J., concurring in part: "promises swollen verdicts"). See also United States v. 3.544 Acres of Land, 147 F.2d 596, 598 (3d Cir. 1945) ; Eagle Lake Improvement Co. v. United States, 141 F.2d 562, 564 (5th Cir. 1944); Housing Authority v. Green, 200 La. 463, 474, 8 So. 2d 295, 299 (1942) ; Sawyer v. Commonwealth, 182 Mass. 245, 247, 65 N.E. 52, 53 (1902) ; In re Slum Clearance, 332 Mich. 485, 496, 52 N.W.2d 195, 200 (1952); Banner Milling Co. v. New York, 240 N.Y. 533, 540, 148 N.E. 668, 670 (1925) ; In re CrossBronx Expressway, 195 Misc. 842, 852, 82 N.Y.S.2d 55, 68 (Sup. Ct. 1948); Cleveland Boat Serv., Inc. v. Cleveland, 136 N.E.2d 274, 275 (Ohio 1956).

44. United States v. Building Known as 651 Brannan Street, 55 F. Supp. 667, 670 (N.D. Cal. 1944) ("If personal damage or detriment were intruded, the test of fair market value would become completely unstandardized and illusory.") ; Housing Authority v. Holloway, 63 Ga. App. 485, 4SS, 11 S.E.2d 418, 420 (1940) (dissenting opinion: " $[F]$ air market value is the final criterion of the measure of damages. . . [ [T]o find its worth to the owner is to open the door to the wildest kind of speculation ....").

45. See, generally, Note, Good Will, 53 CoLux. L. REv. 660 (1953). These differences include questions of considering good will as an item in a company's balance sheet, amortization and depreciation as well as valuation. See also Foreman, Conflicting Theories of Good Will, 22 Colum. L. Rev. 638 (1922).

46. United States v. Inlots, 26 Fed. Cas. No. 15441, at 489 (C.C.S.D. Ohio 1873) ; St. Louis v. St. Louis I.M. \& S. Ry., 266 Mo. 694, 705, 182 S.W. 750, 753 (1916) (awards would be too variant); Springfield S.W. Ry. v. Schweitzer, 173 Mo. App. 650, 655, 158 S.W. 1058, 1059 (1913).

47. See, e.g., Bailey v. Boston \& P.R.R., 182 Mass. 537, 539, 66 N.E. 203, 204 (1903) ("The business might chance to be exceedingly profitable at the time of taking, so that an interruption of it from an interference with the full use of the real estate might cause a loss far greater than the reasonable rental price of the property ...."); Sauer v. Mayor, 44 App. Div. 305, 308, 60 N.Y. Supp. 648, 650 (1st Dep't 1899) ("That the plaintiff had made profits in his business in the past was no indication that he would continue to make them in the future ....").

48. Contract: Standard Mach. Co. v. Duncan Shaw Corp., 208 F.2d 61 (1st Cir. 1953) (lost profits ascertained even though business had yet to begin); Perkins v. Langdon, 237 N.C. 159, 74 S.E.2d 634 (1953) (damages for lessor's repudiation of three year lease based on estimated profits); Pace Corp. v. Jackson, 284 S.W.2d 340 (Tex. 1955) 
been able to measure these losses in condemnation cases. In England and Canada, reasonable recoveries for such injuries, which for many years have been held compensable, have resulted without undue difficulty. ${ }^{49}$ In this country. on their own initiative in partial takings as well as under legislative direction in special takings, courts have included incidental damages in their judgments without complaint of difficulties in determining the appropriate award. ${ }^{50}$

Moreover, the market value formula, while generally recognized as basic to any system of compensation, has not proved sufficiently objective. Unquestionably, market value is a foundation upon which any method of compensation must be built. Despite shortcomings, it enables the courts to establish awards with some degree of objectivity. ${ }^{51}$ As was discovered in England, utilizing a formula such as "value to the owner" results in entirely unpredictable compensation and excessive condemnation costs. ${ }^{52}$ But denying compensation for incidental losses because of fear that such action would undermine the

(estimation of future profits where continuation of a going concern is prevented); Wood v. Pender-Doxey Grocery Co., 151 Va. 706, 144 S.E. 635 (1928) (loss of good will). See Webster v. Beau, 77 Wash. 444, 450, 137 Pac. 1013, 1015 (1914), in which the court stated: "[W]here an established business has been interrupted or destroyed by breach of contract, or by tort, a resulting loss of profits may become the basis of a recovery, there being a past experience sufficient to render the extent of such loss reasonably certain, and fairly susceptible of proof." See also Wilson v. Wernwag, $217 \mathrm{~Pa}$. 82, 66 Atl. 242 (1907); Collins v. Lavelle, 19 R.I. 45, 31 Atl. 434 (1895) ; Matter of Brown's Will, 211 App. Div. 662, 208 N.Y. Supp. 359 (1st Dep't 1925) ; 5 CoRBin, Contracts $\$ \$ 1020,1023,1029$ (1950); MCCoRMICK 97-99, 111.

Tort: Roseland v. Phister Mfg. Co., 125 F.2d 417, 420 (7th Cir. 1942) (expected profits allowed in restraint of trade suit) ; Johnson v. Railroad, 140 N.C. 574 , 578-79, 53 S.E. 362,364 (1906) (prospective profits allowed where factory tortiously burned). See also 1, 2 HARPER \& JAMrEs, ToRTs $\$ \S 6.13,25.3$ (1956); Nims, Damages and Accounting Pracedure in Unfair Competition Cases, 31 CoRnell L.Q. 431 (1946) ; Wright, Tort Responsibility for Destruction of Good Will, 14 CoRnell L.Q. 298 (1929); Note, The Requirement of Certainty in the Proof of Lost Profits, 64 HARv. L. REv. 317, 318 (1950); Note, 7 Stan. L. REv. 97, 111 (1954).

Taxation: Adams Express Co. v. Ohio, 166 U.S. 185, 221 (1897) (good will thing of value and taxable as such); Raytheon Production Corp. v. Commissioner, 144 F.2d 110 (1st Cir.), cert. denied, 323 U.S. 779 (1944) ; Richard S. Wyler, 14 T.C. 1251 (1950). See Armstrong, Tax Valuation of Good Will, 1951 U. So. Calrr. TAx. INST. 453; Schwartz, Good Will in Tax Lawe, 8 TAX L. Rev. 96 (1952) ; Note, 1 Stan. L. Rev. 64 (1948).

49. See notes $24,25,32$ stipra.

50. See notes 99,115 infra and accompanying text.

51. As one authority has put it, market value is the "faute de mieux:" 1 Orgez $\S 15$. Later, the author questioned "whether the increasing vagueness of the standard does not destroy its practical utility." Id. $\S 36$. See also 1 BoNBRIGHT 447-49.

52. See Ministry of Reconstruction, Second Report of the Consamittee Dealing with the Law and Practice Relating to the Acguisition and Valuation of Lasd FOR PUBLIC PuRPoses 8 (Scott Rep. 1918). The report asserted that the value to the owner criterion often produced "highly speculative elements of value which had no real existence." Moreover, it was felt that the alternative, value to the taker, also gave the owner too much. See also 1 Bonbright 449 n.89. But cf. Pawson v. City of Sudbury, [1953] Ont. 988. These criticisms did not apply to incidental losses, as is demonstrated by the continued allowance of such losses after the abandonment of the value to owner test. See note 25 supra and accompanying text. 
objectivity of the market value formula requires overlooking serious imperfections in that standard. In the final analysis, market value is a theory, not a fact. The system produces radically inconsistent results. A 1932 study of condemnation practices in New York City illustrates that in practice market value is anything but objective: expert appraisals made for the condemnor and for the condemnee generally varied by about one hundred per cent. ${ }^{53}$ Analysis of data on more recent Massachusetts takings reveals this inconsistency more startlingly. ${ }^{\text {st }}$ Not only do the figures confirm the New York findings-the difference between appraisals averaging fifty-six per cent and ranging to a maximum of five hundred seventy-one per cent-they represent the estimates of two or more state experts, each acting on behalf of the condemnor and apparently lacking the conflicting interest which might be said to underlie the divergent estimates of the earlier New York study. ${ }^{55}$ These statistics suggest that the "objectivity" difficulties posed by incidental losses may not significantly differ from those presently obscuring the market value standard. ${ }^{\text {.0 }}$

53. Wallstein, Report on Law and Procedure in Condensnation iv (1932). See also id. at app. C.

54. The Massachusetts figures are derived from the weekly calendars of the Governor's Council meetings, Jan. 5, 1956-Jan. 2, 1957. These cases, requiring some court action, constituted approximately $20 \%$ of the total number of state land takings that necessitated approval of the Council during that period.

55. At least two outside appraisers were called in by the state to evaluate the properties in 114 of the 188 takings that necessitated court approval. The total amount of the low estimates was approximately three million dollars; the total amount of the high estimates was slightly over four million dollars. The average gross difference was $32 \%$; the average percentile difference was $56 \%$. In 17 of these cases, the difference came to over $100 \%$.

The 10 awards requiring court approval and passed upon by the Council in December 1956 (including Jan. 2, 1957) are illustrative of the wide difference between the appraisers' estimates:

\begin{tabular}{ccc}
\hline \hline Lower appraisal & Higher appraisal & \% Difference \\
\hline$\$ 1,272$ & $\$ 4,141$ & 226 \\
10,500 & 13,773 & 31 \\
23,000 & 33,500 & 46 \\
1,874 & 3,653 & 95 \\
17,500 & 24,300 & 39 \\
53,600 & 54,500 & 2 \\
7,800 & 8,552 & 10 \\
1,312 & 7,623 & 481 \\
23,000 & 23,500 & 2 \\
26,310 & 67,300 & 156 \\
\hline
\end{tabular}

56. For striking examples of how divergent the estimates of many expert witnesses are concerning market value in particular takings, see Oklahoma City v. Wilson, 310 P.2d 369, 372 (Okla. 1957) (condemnor's appraiser's figure- $\$ 4,200$, condemnee's appraiser's figure- $\$ 42,400)$; State Roads Comm'n v. Novosel, 203 Md. 619, 625-26, 102 A.2d 563, 566 (1954) ( $\$ 2,000$ as against $\$ 54,348)$; Reeves v. Dallas, 195 S.W.2d 575,580 (Tex. Civ. App. 1946) ( $\$ 1,000$ as against $\$ 100,000)$; In re Civic Center, 335 Mich. 528, 531-32, 56 N.W.2d 375, 376 (1953) ( $\$ 300,000$ as against $\$ 603,851)$; Tulsa County Drainage Dist. v. Stroud, 198 Okla. 688, 181 P.2d 1000 (1947) ( $\$ 600$ as against $\$ 30,000)$. See also United 


\section{Market Value: A Pragimatic View}

In theory, the market value system provides for two separate determinations. Initially, a taking must be found; the existence of a taking is gauged by the gain inuring to the condemnor. ${ }^{57}$ Once the fact of a taking has been established, the measure of compensation is determined according to prevailing market price. Despite this black-letter approach, courts, either by stretching the market value standard or by frankly admitting that its strict application would be unjust, have often granted compensation for incidentals to avoid an otherwise unconscionable award. ${ }^{58}$ As a result, the standard in practice operates unequally, with some condemnees fully indemnified while many others are forced to bear considerable losses. Thus, although these judicial techniques may produce desirable results when utilized, they do not operate to effect a uniform system for compensation of incidental losses. Rather, as instances of departure from the market value standard, they cast further doubt on the wisdom of maintaining that formula as a barrier to compensating such losses.

\section{Good Will}

Of the incidental losses resulting from condemnation, good will is perhaps the most frequently recurring and the most vexatious. One form of good will, that which inheres in the real estate itself, is normally compensable since it is included as a part of the market value formula; property is evaluated according to its "best available use." ־ֶ But a second category of good will, one enjoyed by most small businessmen, is more personal. It inheres in the business aside from the physical property and grows from the

States v. 37.15 Acres of Land, 77 F. Supp. 798, 800-01 (S.D. Cal. 1948) ("I cannot help but conclude that there is an excess minimization of values on the one side and over enthusiasm on the other-a phenomenon not untypical of condemnation cases.").

Commentators have pointed to the frequent variances in appraisal figures. See, e.g., Dolan, New Federal Procedure in Condemnation Actions, 39 VA. L. Rev. 1071, 1081 (1953). Those in the profession have recognized this shocking situation and have repeatedly expressed their disapproval. See Editorial, Unreasonable Differences of Opinion, 23 APPRAISAL J. 322 (1.955) (discussing the many occasions on which differences were more than 100\% apart). See also Friedmann, Selection of Appraisers for Condemnation, 23 APPRAISAL J. 363 (1955) (numerous references to widely divergent estimates) ; Kniskern, The Difficulties and Menaces in Professional Practice, 23 Appraisat J. 334 (1955).

57. 1 ORGEL § 3.

58. " '[T] value and ... what the law has so generally adopted is a single form of words rather than a single standard of value." 1 BonsRiger 413 .

59. Market value in eminent domain is determined by ascertaining the present or potential worth of a piece of property, taking into consideration all the available or the best available uses which can be made of the property. See 1 Orgel $\$ 30$; Note, Good Will, 53 Colums. L. Rev. 660, 675 (1953). See also United States v. Wateree Power Co., 220 F.2d 226, 232 (4th Cir. 1955); United States v. Becktold Co., 129 F.2d 473, 478 (8th Cir. 1942) ; Banner Milling Co. v. New York, 240 N.Y. 533, 540, 148 N.E. 668 , 670 (1925). 
personality and ability of the proprietor, the reputation of the business and the customers' habit of dealing with a firm due to its tradition and familiarity. ${ }^{60}$ For this type of good will, often completely destroyed or greatly damaged when the owner must move from the neighborhood to some other locale, American courts rarely admit giving compensation. ${ }^{61}$ Yet loss of such good will is a particularly acute factor in present-day condemnations, like urban renewal programs, where mass takings in concentrated areas make relocation nearby increasingly difficult.

In rejecting claims for loss of good will, courts generally argue that no property was taken or that the loss is speculative. ${ }^{62}$ At times, they also contend that good will losses are de minimis. ${ }^{63}$ But dismissing such a loss, as one court has, by stating that "a good plumber should be able to continue his business in almost any location and do as well as he formerly did in a neighborhood where in many homes there was a lack of adequate plumbing facilities,"64 expresses business naiveté, especially since courts denying good will compensation have recognized that the businesses were irreparably destroyed by con-

60. While many definitions are given for this type of good will, Note, Good Will, 53 Colum. L. Rev. 660, 664-65 (1953), the definition of Judge Story is particularly applicable: "[T]he advantage or benefit which is acquired by an establishment beyond the mere value of the capital, stock, funds, or property employed therein, in consequence of the general public patronage and encouragement which it receives from constant or habitual customers, on account of its local position or common celebrity, or reputation for skill or affluence, or punctuality, or from other accidental circumstances or necessities, or from ancient partialities or prejudices." STORY, PartNERShIP $\$ 99$ (7th ed., Wharton 1881). See also 1 ORGEL \$ 75; McCoRMICK 537.

61. See note 5 supra. Germane to, and often indistinguishable from, good will is what is sometimes referred to as "going concern value." E.g., in Kimball Laundry Co. v. United States, 338 U.S. 1 (1949), the Court spoke of "going concern value" though it gave this phrase the same meaning as good will. See Note, Good Will, 53 CoLUM. L. REv. 660, 677 n.100 (1953). See also Banner Milling Co. v. New York, 240 N.Y. 533, 543, 148 N.E. 668,671 (1925). While going concern value is a broader term than good will, courts disallow compensation for its loss in so far as it includes the elements of patronage or value in excess of market value. See Chicago v. Farwell, 286 I11. 415, 425, 121 N.E. 795, 798-99 (1919) ; Banner Milling Co., supra at 542-44, 148 N.E. at 671. But cf. United States v. Becktold Co., 129 F.2d 473, 477-78 (8th Cir. 1942).

62. People v. Johnson \& Co., 219 App. Div. 285, 290, 219 N.Y. Supp. 741, 746 (1st Dep't 1927), aff'd, 245 N.Y. 627, 157 N.E. 885, cert. denied, 275 U.S. 571 (1927) (not included within taking); Banner Milling Co. v. New York, supra note 61 , at 540, 148 N.E. at 670 (sovereign need pay only for what it takes; also speculative); Sawyer v. Commonwealth, 182 Mass. 245, 247, 65 N.E. 52, 53 (1902) (speculative); Edmands v. Boston, 108 Mass. 535, 549 (1871) (noncompensable property loss).

63. See, e.g., Kimball Laundry Co. v. United States, 338 U.S. 1, 12 (1949) ("In the usual case, most of it can be transferred."); Banner Milling Co. v. New York, 240 N.Y. 533, 540, 148 N.E. 668, 670 (1925) ("The owner may carry his good will with him."); In re Jeffries Home Housing Project, 306 Mich. 638, 651, 11 N.W.2d 272, 276 (1943). At times, courts speak of incidental losses as "mere consequential injuries," though the condemnee may incur significant loss. See, e.g., American Tel. \& Tel. Co. v. Maguire, 219 La. 740, 743 n.2, 54 So. $2 d$ 4, 5 n.2 (1951).

64. In re Jeffries Home Housing Project, supra note 63. 
demnation..$^{65}$ In contrast, some courts have moved outside the strictures of the market value formula and have compensated for loss of good will. ${ }^{66}$ In permitting payment for this incidental loss, however, they have verbally conformed to the market value standard by considering good will a factor to be included within the general formula rather than a separate allowance. ${ }^{67}$ The tendency to broaden the market value test by this means is indicative of the general procedure utilized to overcome or ignore the restrictions imposed by that standard.

\section{Moving Expenses}

As in the denial of all incidental losses, courts generally hold moving expenses noncompensable since they do not constitute gain to the taker. ${ }^{\circ 8}$ Of course, application of this in rem criterion of taking is itself sufficient to deny compensation. Nevertheless, courts have raised additional contentions to justify denial of payment for moving costs. Perhaps most paradoxical is the assertion that these costs, as all incidental losses, are included within the market value formula. ${ }^{69}$ Such a proposition conflicts with the oft-repeated statement that while these losses are in fact losses, they are noncompensable. ${ }^{70}$ Moreover, this reasoning does not survive the test of the market place. It

65. Mitchell v. United States, 267 U.S. 341 (1925) ; Bothwell v. United States, 254 U.S. 231 (1921) ; Banner Milling Co. v. New York, 240 N.Y. 533, 148 N.E. 668 (1925).

66. E.g., Housing Authority v. Lustig, 139 Conn. 73, 90 A.2d 169 (1952), wherein the court concluded that the value of the business is in the market value formula. At other times, courts are prone to assert that the property has no market value; therefore, some other test is employed. "[M]arket value is not a universal test, and cases often arise where some other mode of ascertaining value must be resorted to." Beale v. Boston, 166 Mass. 53, 55, 43 N.E. 1029, 1030 (1896). See 1 BonRRigHT 420: "A judge is . . likely to hold that the property in question has no market value if he is convinced there is a wide and measurable discrepancy between the price which it would have commanded on the market place and its value (devoid of sentimental considerations) to the owner himself."

67. In the Lustig case, supra note 66 , the court included the value of the business as an element of market value. The committee that assessed damages concluded that the value of the property was $\$ 6,500$ and the value of the established poultry slaughtering business was $\$ 10,000$. In awarding the condemnee $\$ 16,500$, the court felt that the "highest economic use" would make this particular property worth the larger amount. See 26 CoNN. B.J. 404, 406-07 (1952); note 7.1 infra.

68. See note 6 supra. See also Edgecomb Steel v. New Hampshire, 131 A.2d 70 (N.H. 1957); McGhee v. Floyd County, 97 S.E.2d 529 (Ga. 1957).

69. See St. Louis v. St. Louis I.M. \& S. Ry., 266 Mo. 694, 706, 182 S.W. 750, 753 (1916) ; MCCoraICK 541. Generally, this argument is advanced in cases where the court seeks to permit the introduction of evidence justifying the inclusion of these elements in the compensation award. See, e.g., Harvey Textile Co. v. Hill, 135 Conn. 686, 689-90, 67 A.2d 851, 852-53 (1949); In re Widening of Gratiot Avenue, 294 Mich. 569, 577, 293 N.W. 755, 758 (1940). See also United States v. General Motors Corp., 323 U.S. 373, 383 (1945).

70. See United States v. General Motors Corp., supra note 69, at 379; Oakland v. Pacific Coast Lumber and Mill Co., 171 Cal. 392, 398, 153 Pac. 705, 707 (1915) ; Newark v. Cook, 99 N.J. Eq. 527, 538, 133 Att. 875, 879 (Ch. 1915). 
presumes that the seller's removal costs are assumed by the buyer and are therefore reflected in the ultimate price of the property. But it neglects the fact that the inflating effect of the seller's moving expenses are, on the whole, balanced by the deflating effect of the buyer's expenses. ${ }^{71}$ Accordingly, the most a seller could collect as moving costs would appear to be that fraction which results from the compromise with the buyer, who is also seeking to defray his expenses.

The other rationales used to deny moving costs exaggerate the exceptional situations and ignore the more conventional practices. Courts often disallow compensation for these expenses on the ground that the condemnee would eventually have to incur removal costs when at some future time he willingly would move to other premises. ${ }^{72}$ Additionally, they contend that were a condemnee allowed moving expenses, he would be permitted unjustifiably to pick a new location at his whim and caprice. ${ }^{73}$ But in reality, these arguments appear as makeweights used by the courts to justify their denial of incidentals. They have been advanced even when a condemnee's moving expenses at the time of condemnation have been proved necessarily greater than those which would exist at some future date, ${ }^{74}$ or when the condemnee has not acted upon whim in relocating after condemnation, but has incurred only reasonable expenses. ${ }^{75}$ Furthermore, contrary to the assumption implicit in these arguments, the majority of businessmen forced to move by condemnation might

71. See 1 Orgel $\$ 68$ n.2; Highway Comm'n v. Superbilt Mfg. Co., 204 Ore. 393, 420-21, 281 P.2d 707, 719-20 (1955). In the case of sales by lessors, of course, removal costs are likely to be absent. Hence, only the deflating effect of the buyer's expenses would remain. Another reason advanced to show that the market value formula does not include remuneration for incidental expenses is that the market value of property is largely determined by the value set for vacant or about-to-be-vacant property; therefore, since the sellers of such property do not have to bear removal expenses, such costs are not refleoted in market value. MCCoRMICK 541-42. At least in one case a third contention has been raised. In St. Louis v. St. Louis, I.M. \& S. Ry., 266 Mo. 694, 707, 182 S.W. 750,753 (1916), the court found no need to compensate for removal expenses in eminent domain, since in voluntary sales "ordinarily" neither party considers the costs of removal in determining the price of the property.

72. See, e.g., United States v. Inlots, 26 Fed. Cas. 482 , No. 15441 (C.C.S.D. Ohio 1873) ; Louisiana v. Ferris, 227 La. 13, 23, 78 So. 2d 493, 496 (1955) ; Springfield S.W. Ry. v. Schweitzer, 173 Mo. App. 650, 158 S.W. 1058 (1913); New York Cent. \& H.R.R.R. v. Pierce, 35 Hun. 306 (N.Y. Sup. Ct. 1885).

73. See United States v. Building Known as 651 Brannan Street, 55 F. Supp. 667, 670 (N.D. Cal. 1944); Springfield S.W. Ry. v. Schweitzer, supra note 72, at 655. See also Housing Authority v. Holloway, 63 Ga. App. 485, 488, 11 S.E.2d 418, 420 (1940) (dissenting opinion).

74. See 1 OrgeL $\S 69$; cf. New York Cent. \& H.R.R.R. v. Pierce, 35 Hun. 306 (N.Y. Sup. Ct. 1885).

75. See, e.g., St. Louis v. St. Louis I.M. \& S. Ry., 266 Mo. 694, 698, 182 S.W. 750, 751 (1916) ("It is conceded even that, if these three items were proper subjects of damage, then the amount allowed the respondent therefor is fair and reasonable."). See also United States v. 40.558 Acres of Land, 62 F. Supp. 98, 100-01 (D.C. Del. 1945) ; Highway Comm'n v. Superbilt Mfg. Co., 204 Ore. 393, 281 P.2d 707 (1955). 
not otherwise have incurred the cost of moving. Many businesses never move away from their initial sites; numerous enterprises go out of business altogether rather than continue operations in a new area; quite frequently an entire business, including its stock, is sold; and often, a business liquidates its inventories and other physical assets prior to a planned change of situs. ${ }^{76}$ Even when a businessman does move, either independently or after condemnation, one can not validly assume that he will act unreasonably and for other than profit motives. Both of the arguments advanced by the courts will, upon occasion, undoubtedly be valid. But they now serve to deny compensation in all condemnation situations rather than in isolated exceptions. And the individual cases where the condemnee obviously acts on caprice or where moving costs would otherwise have been imminent and certain might better be treated through judicial discretion within a positive framework of compensation than through an automatic exclusion of all claims.

Despite the standard noncompensatory policy, some courts have provided for moving expenses, usually by reshaping the market value formula. A typical example can be found in a recent Connecticut case, Harvey Textile Co. v. Hill. ${ }^{77}$

76. An informal survey of condemnees in a current redevelopment program in New Haven, Connecticut indicates that the judicial assumptions concerning moving expenses may be erroneous. Twenty-five firms selected at random were polled. Of these, 13 had never moved from their original sites; the length of time these sites were occupied varied from 2 to 40 years, with 1 businessman having remained in his original location "all his life." The average occupancy was somewhat over 18 years. Of the 12 firms who had changed premises, 10 had not moved a distance of more than 200 yards. Data available in Yale Law Library.

77. 135 Conn. 686, 67 A.2d 851 (1949).

A principal means by which courts are able to circumvent the restriction against compensation for removal costs is to declare that the properties to be moved (c.g., machinery, appliances) constitute permanent fixtures and therefore warrant compensation.

A majority of courts allow owners removal costs of such "fixtures." See United States v. Becktold Co., 129 F.2d 473, 477 (8th Cir. 1942); Des Moines Wet Wash Laundry v. Des Moines, 197 Iowa 1082, 198 N.W. 486 (1924); In re Slum Clearance, 332 Mich. 485, 52 N.W.2d 195 (1952) ; In re Widening of Gratiot Avenue, 294 Mich. 569, 293 N.W. 755 (1940) ; State v. Dockery, 300 S.W.2d 444 (Mo. 1957); 4 Nichols 398; Note, 23 TExas L. Rev. 402 (1945). For a thorough discussion of the factors involved regarding fixtures, see Highway Comm'n v. Superbilt Mfg. Co., 204 Ore. 393, 281 P.2d 707 (1955) ; In re Theodore A. Kochs Co., 120 F.2d 603 (7th Cir. 1941); In re Post Office Site, 210 Fed. 832 (2d Cir. 1914). See also United States v. General Motors Corp., 323 U.S. 373 (1945), where the Court asserted that the owner is to be compensated for such permanent fixtures even though the government does not take over such property; condemnation is tantamount to destroying the use of the fixtures is sufficient. But cf. Mitchell v. United States, 267 U.S. 341 (1925). Other courts, however, refuse to reimburse owners for "fixtures" that can be removed. Potomac Elec. Power Co. v. United States, 85 F.2d 243 (D.C. Cir. 1936) ; Furtrovsky v. United States, 66 F.2d 215 (D.C. Cir. 1933) ; Mayor v. Gamse \& Bros., 132 Md. 290, 104 Atl. 429 (1918).

But generally personal property not attached to the real estate as a permanent fixture is not compensated for, and the owner must suffer removal costs. See Edgecomb Steel v. New Hampshire, 131 A.2d 70, 79 (N.H. 1957). See also Diamond, Condemnation Law, 23 APPRAISAL J. 564, 577-78 (1955). Condemnees who are tenants, therefore, are generally 
There, the condemnee was awarded the expenses he had sustained in removing machinery from his factory; the court considered as part of the market value formula all those costs which an owner could urge as affecting the sales price of his property. Since the owner would demand that his moving expenses be included within the ultimate price, the court felt this sum to be an element of market value. ${ }^{78}$ Carried to its logical extreme, such reasoning would include all incidental losses within the market value standard. Since these expenses do not constitute a realistic factor in market value computations, ${ }^{79}$ the results produced by this rationale should be achieved by other means.

Apparently aware of the adverse effects which denial of moving expenses might have upon urban renewal programs, Congress has recently approved payment of up to twenty-five hundred dollars to business concerns taken in urban renewal but not otherwise compensated for such expenses. ${ }^{80}$ While this legislation results in fuller indemnity to the condemnee, it does not eliminate the hardship of more severe cases. Businesses may incur far greater moving expenses than are contemplated by the statutory maximum. Still, the congressional action remains another indication of the growing awareness that the market value formula fails to grant adequate compensation. ${ }^{81}$

not compensated for removal costs of fixtures which are not usually considered as permanent by the courts and are treated like other personal property for which there is no compensation. See Highway Comm'n v. Superbilt Mfg. Co., supra at 413-14. But see In re John C. Lodge Highway, 340 Mich. 254, 65 N.W.2d 820 (1954).

7S. In United States v. General Motors Corp., supra note 77, the Supreme Court employed the same reasoning in a temporary taking. Such logic led one writer who opposes compensation for incidental losses to comment: "From a valuation standpoint this admonition [not to allow incidental losses apart from market value] is equivalent to the solemn directive given by the mother to her daughter when she asked to go swimming: 'Yes, my darling daughter, hang your clothes on a hickory limb, but don't go near the watir:" Dolan, "Just Compensation" and the General Motors Case, 31 VA. L. REv. 539, 543 (1945). See also Douglas, J., concurring in part in General Motors, supra at 385.

79. See note 71 sipra and accompanying text.

80. As passed, it allowed $\$ 2,000$ and $\$ 100$ respectively. 70 STat. 1101 (1956), 42 U.S.C. $\$ 1456$ (Supp. IV, 1957). The measure originally had called for a $\$ 5,000$ maximum for moving business property and $\$ 200$ for personal effects when a residence is condemned. House Committee on Banking and Currency, Report on Honsing Act of 1956, H.R. REP. No. 2363, S4th Cong., 2d Sess. 2S-29 (1956). In 1957 Congress amended the act to allow $\$ 2,500$ for moving expenses of businesses and $\$ 100$ payment to individuals or families to be given "in lieu of" whatever moving costs they may incur. See Conference Report, Housing Act of 1957, H.R. REp. No. 659, 85th Cong., 1st Sess. 7-8 (1957) ; 71 STAt. 300, Pub. L. No. 85-104, 85th Cong., 1st Sess. $\$ 304$ (July 12, 1957). Significantly, by this latter provision $\$ 100$ will at times be given though moving costs may not amount to that figure. In effect, then, some condemnees (not including businesses) are to receive a small stipend for general inconvenience.

81. In 1952, Congress authorized payment up to $25 \%$ of the market value of the condemned property for moving costs incurred by condemnees in public works undertaken by the Department of Defense. Act of July 14, 1952, § 401 (a), 66 STAT. 624. New York has enacted a measure to pay moving costs in housing project developments up to $\$ 500$ for business and commercial condemnees not otherwise compensated for such damages. New York Sess. Laws 1957, c. 798, § 1. 


\section{Lost Profits}

Perhaps most serious, and generally most difficult to ascertain, are the losses resulting from interruption of the condemnee's business or his inability to relocate. All the arguments advanced against granting awards for incidentals are utilized by the courts in denying compensation for these damages, ${ }^{82}$ even though such denial may seriously, and often permanently, injure the economic position of the enterprise concerned. Business interruptions, which are seldom avoidable, are often of considerable duration; some businesses, both large and small, can rarely re-establish as going concerns within a matter of days, or even weeks. And the effect of interruptions, especially in retail trade where annual profits are largely dependent on volume, may be sufficient to eradicate the earnings of an entire year. True, a condemnee may know of the impending taking months in advance and prevent the interruption and its concomitant loss. ${ }^{83}$ But such action would force the condemnee to bear without compensation the expense of two sites for the period prior to the time of eviction.

Moreover, a condemnee often suffers more permanent damage. He may be forced to bear increased expenses for comparable property. ${ }^{84}$ In urban renewal programs, for example, the condemnation of large areas of land may cause a diminution of available sites resulting in higher costs for the remaining property. ${ }^{85}$ Since the market value of the condemned property is established as of the time of the taking, this increase is not reflected in the award. ${ }^{80}$

82. See note 7 supra. See also Diamond, supra note 77 , at 576 .

Profits lost due to interruption of business have been compensated for in partial taking cases. See In re Slum Clearance, 332 Mich. 485, 495, 52 N.W.2d 195, 199-200 (1952); Dallas v. Priolo, 150 Tex. 423, 242 S.W.2d 176 (1951). See note 99 infra.

83. Public knowledge that an area is slated to be condemned often has an adverse effect on owners of land and business. People tend to move away before the day of taking, and others are reluctant to move into the premises so vacated. Lessors, therefore, lose tenants, and property valuations plummet before the date of taking and valuation. See Report of Massachusetts Special Commission Relative to Certain Matters Pertaining to the Taking of Land by Eminent Domain, House No. 2738, p. 13 (1956) (hereinafter cited as Massachusetts Report). Furthermore, trade is drastically curtailed as the area loses population. On the other hand, advance knowledge might lead to "wash sales" designed to make the property appear more valuable than in fact it is. See WaLLSTEIN, REPORT on Law and Procedure in Condenination y (1932).

84. See United States v. Inlots, 26 Fed. Cas. No. 15441, at 489 (C.C.S.D. Ohio 1873) ; Louisiana Highway Comm'n v. Boudreaux, 19 La. App. 98, 139 So. 521 (1932) ; Fiorini v. Kenosha, 208 Wis. 496, 243 N.W. 761 (1932). See also 4 Nichous 415.

85. See In re Slum Clearance, 332 Mich. 485, 496, 52 N.W.2d 195, 200 (1952). See also Slonim, Injustices in Eminent Domain, 25 Appraisal J. 421, 423 (1957): "Often a home owner or the owner of a business site in a neighborhood where the properties are moderately priced is compelled to sell for a sum of money which will be inadequate to pay for similar property in a different section of the town, thus necessitating a substantially larger outlay of funds. In many cases he may not be in a position to raise the excess amount required. This happens frequently where freeways require the taking of numerous properties."

86. In almost all instances, the property is valued at the "time of taking." United States v. Miller, 317 U.S. 369, 374 (1943); United States v. Chandler-Dunbar Water 
Further, a condemnee may not be able to relocate at all. ${ }^{87}$ Or, a fee owner may lose an especially advantageous lease since he can recover from the condemnor no more than the market value of the rental space. ${ }^{88}$ Although courts occasionally juggle the market formula to indemnify the condemnee for such losses, ${ }^{80}$ as a rule they are held noncompensable..$^{90}$ Admittedly, granting compensation in many instances would have the effect of insuring the condemnee of continual profits. ${ }^{01}$ But where the condemnee incurs either an out-of-pocket expense or a highly probable future loss of profits, this objection appears without substance. ${ }^{92}$

\section{Some Important Recognized Exceptions}

While courts often extend market value theory to grant compensation for incidental losses, in a number of important areas they have been more forthright in carving out exceptions to that standard. Thus, when treating partial, temporary or unusual takings and special types of property, they have stated that a strict market value test is inapplicable and have applied some modified standard for evaluating loss. The circumstances surrounding such situations do not, however, significantly differ from those in which losses have been held noncompensable. And the logic of the courts in malking these exceptions

Power Co., 229 U.S. 53 (1913) ; see 3 NICHoLs 18. In a few states, however, statutes fix a different date of valuation, e.g., "date of summons." CAL. ConE CIv. Proc. $\S 1249$ (Deering Supp. 1957). For instances in which the governing valuation date is not followed, see note 106 infra.

87. See Mitchell v. United States, 267 U.S. 341 (1925) (inability to find substitute land to raise particular crop); Reeves v. Dallas, 195 S.W.2d 575, 581 (Tex. Civ. App. 1946) (inability to find substitute premises for night club).

This situation is more likely to arise in extensive takings in a concentrated area. Particular businesses that are established to cater to the nature of the condemned neighborhood may find that their services are not in demand because of the different complexion of the changed area, or are not needed or permitted in other surrounding areas. Often such businesses as automobile repair firms, paint shops and chemical companies find it virtually impossible to procure a suitable location not too far removed from their present location due to zoning laws. See Slonim, supra note 85 , at 424 .

88. While no cases seem to have arisen directly in point, the lessor is, by the general rule, prohibited from receiving more than the market value of the premises. 1 ORGEL \& 124; 4 NICHOLS 275-76.

89. See Commissioners of Parks v. Moesta, 91 Mich. 149, 154, 51 N.W. 903, 905 (1892) ; Patterson v. Boston, 40 Mass. (23 Pick.) 425 (1840); cf. notes 66, 67 supra.

90. See note 7 supra. See also United States v. Inlots, 26 Fed. Cas. 490, No. 15441a (C.C.S.D. Ohio 1873) ; Louisiana Highway Comm'n v. Boudreaux, 19 La. App. 98, 139 So. 521 (1932) ; Bailey v. Boston \& P.R.R., 182 Mass. 537, 66 N.E. 203 (1903); Fiorini v. Kenosha, 208 Wis. 496, 243 N.W. 761 (1932); JAHR, EMInent Domatn $\$ 113$ (1953).

91. See notes 47,48 supra.

92. Yet, when a condemnee was able to present undisputed proof of profits made during a five year business history and to show that "orders on hand" would, with reasonable certainty, guarantee similar profits for at least an additional year, he was denied compensation for lost profits due to interruption in business; the court simply ignored the evidence. In re Slum Clearance, 332 Mich. 485, 496, 52 N.W.2d 195, 200 (1952). 
appears incompatible with the arguments they employ to reject incidental loss claims.

The restrictions of the market value standard are most often avoided in "partial takings," in which the condemnor appropriates only a portion of the condemnee's property. ${ }^{93}$ This portion may have a minimal value when judged by the market criterion. Nevertheless, the taking may cause drastic diminution or total destruction of the value of the condemnee's remaining property. ${ }^{04}$ In this event, the courts, repulsed by what they openly term a "travesty upon justice,"95 reject market value of the land taken as the sole measure of compensation. Instead, they allow for the diminution in value of the property remaining in the hands of the condemnee-consequential damages ${ }^{96}$-by adopting different formulae which give rise to greater awards. One formula awards the difference between the value of the entire property before the taking and the value of the property remaining after the taking. ${ }^{97}$ More often used is the quite ambiguous formula allowing for the market value of the part taken, which may be extremely low, plus an award for damages to the remainder. ${ }^{98}$

In creating this exception to market value, the courts have departed from the rule that the condemnor need only pay for the property taken over-a principal ground for denying incidental losses. In addition, some courts have

93. United States v. Miller, 317 U.S. 369, 376 (1943) ; United States v. Grizzard, 219 U.S. 180, 195 (1911) ; Baetjer v. United States, 143 F.2d 391, 394 (1st Cir. 1944); In re Cross-Bronx Expressway, 195 Misc. 842, 847, 82 N.Y.S.2d 55, 62 (Sup. Ct. 1948); Chicago v. Cruse, 337 I11. 537, 539, 169 N.E. 322, 323 (1929).

94. See Pima County v. De Concini, 79 Ariz. 154, 285 P.2d 609 (1955) (value of strip of land taken worth $\$ 2,584$, damage to remainder $\$ 41,906$ allowed); People v. Thompson, 43 Cal. 2d 13, 271 P.2d 507 (1954) (value of strip taken worth $\$ 12,000$, damage to remainder $\$ 17,500)$; American Louisiana Pipe Line Co. v. Kennerk, 144 N.E.2d 660 (Ohio Ct. App. 1957) (value of easement taken $\$ 525$, damage to remainder $\$ 4,050$ ).

95. United States v. Grizzard, 219 U.S. 180, 186 (1911).

96. The term "consequential damage" is almost always used in this country to designate loss of value to the residue not taken in partial taking cases. Actually, howevir, the more appropriate term in these situations is "severance damages," "consequential damages" properly applying to those instances in which property is damaged though no part of the owner's property is taken. See 4 Nrchols 299. See also Rogers, Partial Taking, 25 Appraisal J. 393, 394 (1957). Conforming to practice, the term "consequential damages" is used herein to refer to partial taking situations.

97. See discussion in Finley v. Board of County Comm'rs, 291 P.2d 333, 338 (Okla. 1955); Tulsa County Drainage Dist. v. Stroud, 198 Okla. 688, 181 P.2d 1000 (1947). See also 1 OrGeL $\$ \$ 47-65$, especially $\$ 51$; Diamond, supra note 77 , at 574 .

98. In re Cross-Bronx Expressway, 195 Misc. 842, S47-49, 82 N.Y.S.2d 55, 63-64 (Sup. Ct. 1948); see American Louisiana Pipe Line Co. v. Kennerk, 144 N.E.2d 660, 665 (Ohio Ct. App. 1957). It has been asserted that the same result is reached whether the "value of the land taken plus damages to the remainder" formula or the "before and after" test is applied. See 4 Nichols 336 . While this proposition may be theoretically true, in practice the results are often different. Ibid. A major explanation of this result is the courts' failure to apply the "value of the land taken plus damages to the remainder" formula logically; accordingly, double recoveries are not uncommon under that standard. 1 ORGEL $\S 65$. Both writers prefer the "before and after" test. 
rejected the other basic rationale used to deny incidental losses in total takings, the argument that such payments are speculative, by expressly compensating for incidental losses in partial taking cases. ${ }^{99}$ Yet "consequential" damages, and more particularly incidental losses, seem no more deserving of special treatment in partial takings than do incidental losses in complete takings. If application of a rigid market value standard is a "travesty upon justice" in the former cases, it is hardly less so in the latter instances where the entire business may be destroyed or severely damaged..$^{100}$

Recently, the Supreme Court has established another exception paralleling that of the partial taking. If the taking by the condemnor is "temporary," and the property is to be returned to the condemnee within a specified time, or if property under lease is to be returned before the term of the lease expires, incidental losses will be granted. ${ }^{101}$ The principal case enunciating this doctrine is Kimball Laundry Co. $v$. United States. ${ }^{102}$ There, the federal government had temporarily appropriated a building which the condemnee was leasing for use in his business, and thereby destroyed his trade routes, an element of good will. Limiting its holding to temporary takings, the Supreme Court awarded compensation for this loss. The Court sought to distinguish such situations from takings of the entire fee where good will is held noncompensable; it argued that in the former, unlike the latter, event the condemnee remains saddled with the property temporarily assumed by the government. Accordingly, his future business conduct is rendered uncertain, and he deserves special consideration. ${ }^{103}$ But here again, the condemnee in a temporary taking seems no more deserving of special consideration than a condemnee whose fee is

99. Judicial rejection of the usual formula of market value for the land taken is often accompanied by disregard of the restriction on compensating for incidental losses to the business. Thus, e.g., lost profits because of interruption in business or loss of business may be included as an element of market value in partial taking cases but not when the entire fee is taken. In re Slum Clearance, 332 Mich. 485, 495, 52 N.W.2d 195, 199-200 (1952); Dallas v. Priolo, 150 Tex. 423, 426-427, 242 S.W.2d 176, 179 (1951). Sec Herndon v. Housing Authority, 261 S.W.2d 221, 223 (Tex. Civ. App. 1953).

Florida, by statute, 6 Fla. Stat. ANN. $\$ 73.10$ (Supp. 1956), allows for incidental losses to business property in partial taking cases. Despite broad language in Myers v. Daytona Beach, 158 Fla. 859, 862, 30 So. 2d 354, 355 (1947), the Florida courts appear unlikely to allow compensation for profit losses in any but partial taking situations. See 7 Mrami L.Q. 147, 157 (1953). See also note 34 sitpra.

100. See note 5 supra and accompanying text.

101. See Kimball Laundry Co. v. United States, 338 U.S. 1 (1949); United States v. General Motors Corp., 323 U.S. 373 (1945) ; United States v. Fisk Bldg., 124 F. Supp. 259, 262-63 (S.D.N.Y. 1954). But cf. United States v. Westinghouse Elec. \& Mfg. Co., 339 U.S. 261 (1950), where the Court limited the rule so as not to include removal costs to the condemnee if the condemnor eventually, though not initially, takes the condemnee's whole interest.

102. 33 S U.S. 1 (1949).

103. "The temporary interruption as opposed to the final severance of occupancy so greatly narrows the range of alternatives open to the condemnee that it substantially increases the condemnor's obligation to him. It is a difference in degree wide enough to require a difference in result." Id. at 15 . 
taken and whose entire good will is destroyed. ${ }^{104}$ Perhaps the Court felt the weight of precedent denying incidental losses too formidable to overcome, but that in cases of first impression, it was "free to set forth a more equitable rule."105 Whatever the reasoning, Kimball indicates the Court's willingness to discard the notion that "taking" in condemnation must be equated to "taking over."

The market value test has also been discarded or held inapplicable when valuation is made at unique times or the property has special uses. Thus, if a taking occurred during a period of economic recession or depression, some courts would transfer the valuation date to "normal times" rather than utilize the market test based on property value at the time of taking. ${ }^{100}$ Similarly, property taken during boom times has been devalued to enable better approximation of its true worth. ${ }^{107}$ The theoretical basis for this type of action is obvious. To grant value determined as of depressed times would give the condemnee a fraction of what he would receive if he were a willing seller. On the other hand, to pay in accordance with inflated values might result in an inordinate award. Numerically of more importance are the cases where the market value standard cannot be applied because the condemned property has no readily ascertainable value on the market. Particular kinds of property such as churches, college buildings, clubhouses, unusually expensive residences and certain types of factories are seldom sold on the market. Consequently, the courts adopt as the criterion of compensation "special value to the owner."108 Since this test, in essence, encompasses the loss of the owner, the condemnee is able to have included in his award the incidental damages arising out of the condemnation. Although courts generally will discard the market value test only when dealing with special property, if application of that standard would result in an award far below the value of the property to the owner,

104. See note 65 supra. See also Douglas, J., dissenting in Kimball: "There would be a complete destruction of the trade-routes if the taking of the plant were permanent and a depreciation of them ( $\mathrm{I}$ assume) where it is temporary. Why the latter is compensable when the former is not is a mystery. Even the academic dissertation on valuation which the opinion imports into the Fifth Amendment from accounting literature conceals the answer." 338 U.S. at 23.

105. Comment, 10 Онто Sт. L.J. 83, 85 (1949).

106. Howell v. State Highway Dep't, 167 S.C. 217, 166 S.E. 129 (1932). Contra, Alishausky v. MacDonald, 117 Conn. 138, 167 At1. 96 (1933).

107. Kornegay v. Richmond, 185 Va. 1013, 1025-26, 41 S.E.2d 45, 51 (1947); 1 ORGEI § 25 ; cf. Blincoe v. Choctaw, O. \& W.R.R., 16 Okla. 286, 301-03, 83 Pac. 903, 908-09 (1905).

108. Winchester v. Cox, 129 Conn. 106, 26 A.2d 592 (1942) (park); Idaho-Western Ry. v. Columbia Synod, 20 Idaho 568, 119 Pac. 60 (1911) (college campus); Newton Girl Scout Council v. Massachusetts Turnpike Authority, 138 N.E.2d 769 (Mass. 1956) (recreational camp); In re Simmons, 127 N.Y. Supp. 940, 941 (Sup. Ct. 1910) (church). See also Housing Authority v. Green, 200 La. 463, 474, 8 So. 2d 295, 298 (1942), wherein the court stated: "In cases where there is no market value for a residence sought to be expropriated, the intrinsic value, or its value to the owner, must be taken into consideration; otherwise he might be deprived of his property without just and reasonable compensation." 
they occasionally assert that no market value can be determined even though a market price does exist. ${ }^{109}$ And, as in the special time of taking cases, courts have granted the condemnee a greater than market value award while admitting that the property taken in fact had an ascertainable market value. ${ }^{110}$

Furthermore, certain takings of unusually extensive scope have led to special legislation allowing condemnees compensation for incidental damages. These statutes, first enacted in Massachusetts in 1895, were an outgrowth of wholesale state condemnation directed toward developing municipal water supplies. ${ }^{111}$ The legislatures, recognizing that the taking of huge contiguous areas necessarily restricted successful relocation nearby, sanctioned payment of more than the constitutional minimum. ${ }^{112}$ In other special areas of eminent domain, the federal government and states have enacted legislation requiring payment for incidental losses, particularly moving costs. ${ }^{113}$ Judicial reaction to these statutes has been summarized by Justice Holmes: "It is not forbidden to be just in some cases where it is not required to be by the letter of the para-

109. See 1 Bonbright 419-20. Cf. 1 Orger $\$ 43$ : "In all of the examined cases in which the choice between market value and the value to the owner was at issue, it has been counsel for the owner who has contended that the property should be deemed to 'have no market value' whereas it has been counsel for the condemner who has insisted upon the application of the usual rule of 'fair market value." "

110. In Old South Ass'n v. Boston, 212 Mass. 299, 99 N.E. 235 (1912), the court granted the condemnee an additional $\$ 25,000$ above the market value price; the extra amount represented the loss of tax exemption that belonged to the owner so long as the property remained in his hands. Cf. Housing Authority v. Holloway, 63 Ga. App. 485, 11 S.E.2d 418 (1940), where the court permitted value to be based upon the cost of reproducing the condemned property rather than on the market value; Housing Authority v. Lustig, 139 Conn. 73, 90 A.2d 169 (1952), discussed at notes 66, 67 supra.

Still another area in which courts have made an exception to the market value formula for property taken over is where the owner loses a franchise because of condemnation. See JAHR, EMINENT DoMaIN $\$ 44$. Even in Monongahela, despite the dictum maintaining that the government need only compensate for property it takes over, the Court permitted compensation for the destruction of the condemnee's franchise. See also United States v. Brooklyn Union Gas Co., 168 F.2d 391 (2d Cir. 1948).

In cases where the franchise is not destroyed but real property belonging to a public utility must be moved due to such governmental action as condemnation, the common-law rule is that the cost of relocation is placed upon the utility, providing the governmental authority is acting in a governmental rather than a proprietary capacity. In re Gillen Place, 195 Misc. 685, 90 N.Y.S.2d 641 (Sup. Ct. 1949).

111. See Mass. Acts and Resolves, c. 488, $\S 14$ (1895), c. 450 (1896), c. 450 (1897), c. $321, \S 5$ (1927); 2 Laws of N.Y., c. 724, $\$ 42$ (1905), as amended, 1 Laws of N.Y., c. $314, \S 9$ (1906); Public Laws of R.I., c. 1278, $\$ \$ 12,17$ (1915).

The Indiana court apparently has held that incidental losses are by statute compensatory in all eminent domain cases. See note 34 supra. A similar statute in Florida pertaining to right of way takings may be limited to partial taking situations. See note 99 supra.

112. See Allen v. Commonwealth, 188 Mass. 59, 63, 74 N.E. 287, 289 (1905); Earle v. Commonwealth, 180 Mass. $579,583,63$ N.E. 10 (1902).

113. Congress has allowed moving costs in condemnation for defense projects, see note 115 infra, and defrays some removal costs in the urban renewal program, see note 80 supra. In New York, moving costs up to $\$ 500$ are given in public housing project condemnations. See N.Y. Sess. Laws 1957, c. 798. 
mount law."114 Significantly, courts have neither protested nor suggested the difficulties of measuring incidental losses in any of the cases arising under these statutes. ${ }^{115}$ This attitude toward legislatively created rights serves to augment the courts' self-initiated policy typified by the continual modification and manipulation of the market value standard.

Nevertheless, when courts carve out exceptions to the market value formula or circumvent its restrictions, they invariably stress that market value remains the general standard of compensation in eminent domain. ${ }^{116}$ However, in a recent case, Housing Authority v. Savannah Iron \& Wire Works, Inc., a Georgia court had little reservation in frankly discarding the market value formula. ${ }^{117}$ Ignoring the legal barrier created by case law, the court found the market value standard inapplicable wherever it failed to indemnify the condemnee for all his losses, including incidentals. The assertion is summarized in the approved charge to the jury:

"I further charge you, gentlemen, that the Constitutional provision as to just and adequate compensation does not necessarily restrict the lessee's recovery to market value. The lessee is entitled to just and adequate compensation for his property; that is, the value of the property to him, not its value to the Housing Authority. The measure of damages for property taken by the right of eminent domain, being compensatory in its nature, is the loss sustained by the owner, taking into consideration all relevant factors . . . ."118

By making value to the owner rather than market value the final determinant of compensation, the Georgia court may have candidly adopted a radical policy. Viewed in light of the conduct of many courts and administrators, however, the language rather than the result is surprising.

114. Earle v. Commonwealth, 180 Mass. 579, 583, 63 N.E. 10 (1902).

115. Earle v. Commonwealth, supra note 114 (doctor's good will); Joslin MIfg. Co. v. Providence, 262 U.S. 668 (1923) (moving costs); Matter of Bd. of Water Supply, 211 N.Y. 174, 105 N.E. 213 (1914) (loss of business); People ex rel. Burhans v. City of New York, 198 N.Y. 439, 92 N.E. 18 (1910) (loss of business); Allen v. Commonwealth, 188 Mass. 59, 74 N.E. 287 (1905) ("business" encompasses farmer who sold his produce); cf. Sawyer v. Commonwealth, 182 Mass. 245, 65 N.E. 52 (1902) (statute makes business losses compensable though jury trial need not be given under such circumstances). See also Connor v. Metropolitan Dist. Water Supply Comm'n, 314 Mass. 33, 49 N.E.2d 593 (1943). No cases have arisen on the question of ascertaining moving costs under Act of July 14, 1952, $\$ 401$ (a), 66 STAT. 624 , which allows such expenses in federal military projects.

116. See cases cited notes 106-10 supra. See also Beale v. Boston, 166 Mass. 53, 55, 43 N.E. 1029, 1030 (1896).

117. 91 Ga. App. 881, 87 S.E.2d 671 (1955). In contention in this case were cost of moving and "advertising value" of the condemned property (the latter element being closely akin to good will).

118. $91 \mathrm{Ga}$. App. at $884-85,87$ S.E.2d at 675 . The court admitted that the market value formula is the general measure of damages. However, unlike any other case, it did not state that special conditions need exist to set market value aside. Rather, the general standard was to be discarded if it failed to give fair and reasonable value to the owner. 


\section{Administrative Treatment}

Not only have the courts frequently avoided the confining standard of market value theory and allowed for incidentals, but administrators, negotiators and juries often abandon this restrictive test which tends to deny the condemnee indemnity. ${ }^{110}$ Although condemnees frequently must bear appreciable losses without remuneration, occasionally they are indemnified or even overindemnified. ${ }^{120}$ A number of factors have been influential in effecting this result. The jury's natural sympathy for the condemnee, ${ }^{121}$ the exigencies of administering condemnation programs ${ }^{122}$ and the recognition by all concerned that market value does not permit full compensation are factors which may benefit the condemnee. The New York study revealed that the city courts tended to "split the difference" between the claims of the condemnor and the condemnee. ${ }^{123}$ More significant, condemnors themselves are willing to settle compensation claims by allowing amounts far in excess of market value.

During 1956, one hundred eighty-eight Massachusetts state takings required court, Council and Review Board action to settle condemnation awards. ${ }^{124}$ While the state Review Board determined that the value of the property taken was approximately four million dollars, court action resulted in payment

119. See 1, 2 Orget $\$ \$ 46,247$. See also Watlstein, Report on Law and Procedure in Condenination 187 (1932).

120. See note 119 supra. While there are no definite statistics, fee owners generally seem to receive "liberal" compensation awards in contrast to lessees who must suffer significant losses. See Grutzner, Housing Projects Make Bitter D.P.'s, N.Y. Times, March 18, 1957 , p. 29 , col. 1 , p. 30 , col. 6 . Of course, varying compensation awards are made within each class.

121. Wallstein, Report on Law and Procedure in Condemination 187 (1932). For an example of how juries give compensation for incidental losses, despite apparent directions to the contrary, see Reeves v. Dallas, 195 S.W.2d 575, 580 (Tex. Civ. App. 1946). But cf. Massachusetts Report 10, where it was stated that "a jury trial usually does not materially increase the amount available to the property owner had he accepted a settlement." Part of the reason behind this statement, however, may be the court costs and attorney fees the condemnee must bear by going to trial. See note 125 infra.

122. See note 13 supra. Among other considerations administrators have to deal with is the factor that appraisers, even if competent, often make poor witnesses. Moreover, judges feel themselves not properly qualified to pass upon the evidence of value. Massachitsetts Report 3, 14. See, generally, 2 Orger $\$ 247$.

123. See Wallstein, Report on Law and Procedure in Condennation iv (1932). See also id. at app. C.

Courts tend to seek the "practical" result; thus "splitting the difference" yields the "equitable" result. See, e.g., Louisiana v. Ferris, 227 La. 13, 22-23, 78 So. 2d 493, 496 (1955). It has been asserted that the very vagueness of the fair market standard permits courts "to adjust the rigid rules of law to the requirements of justice and indemnity in each particular case." Frank, J., quoting OrGeL in Westchester County Park Comm'n v. United States, 143 F.2d 688, 691-92 (2d Cir. 1944). The general policy of splitting the difference, however, casts serious doubt as to the wisdom of vagueness in this particular field of law.

124. See note 54 supra. The Review Board is comprised of five members, all members of the real estate profession. The Board was established in accordance with Mass. Acts and Resolves, c. 556, § 6 (1952). 
of five and one-half million dollars to condemnees. This substantial difference demonstrates that the courts are prone to grant awards in excess of the valuation fixed by an apparently unbiased administrative board. Furthermore, it indicates that officials acting on behalf of the condemnor are willing to concede a higher than market value recovery to the condemnee in cases necessitating court action. For in the larger percentage of cases going to trial, the judgment was based upon agreement of the parties. Administrators are confronted with the clear fact that juries as well as judges tend to favor the condemnee: in the eight cases which were tried before a jury, the final award was sixty-three per cent higher than the Review Board estimate. ${ }^{125}$ The willingness of administrators to settle condemnation claims at amounts considerably higher than the putative market value is not surprising in light of these figures. But a principal factor that sways courts and juries to grant high awards is the recognition that the condemnee would otherwise be denied various incidental losses; ${ }^{\mathbf{1 2 6}}$ and this factor appears to influence the actions of appraisers and negotiators as well. At least one appraiser has admitted that he "has heard it said" that appraisers "subconsciously" include incidental losses in arriving at a fair market value figure. ${ }^{127}$

\section{Development, Redevelopment and Utban Renewal}

Recent use of eminent domain exaggerates the need for abandoning the limitations of a strict market value system and for awarding incidental damages. The outdated property concept upon which present evaluation standards are based, the absence of alleged objectivity in market value and the recognized

\begin{tabular}{|c|c|c|}
\hline 125. & Review Board determination & Jury award \\
\hline & $\begin{array}{r}\$ 2,000 \\
54,000 \\
2,000 \\
8,500 \\
18,500 \\
16,500 \\
7,500 \\
7,000\end{array}$ & $\begin{array}{r}\$ 6,414 \\
76,915 \\
13,249 \\
25,303 \\
21,430 \\
13,791 \\
14,188 \\
17,870\end{array}$ \\
\hline & $\$ 116,000$ & $\$ 189,160$ \\
\hline
\end{tabular}

126. See note 119 supra and accompanying text.

127. See Pearl, Appraiser's Guide Under Law Allowing Moving Costs, 21 Appraisal J. 327 (1953). See note 154 infra. A somewhat contrary opinion is at times expressed to the effect that appraisers employed by governmental agencies are biased in favor of the condemnor. See, e.g., Slonim, Injustices of Eminent Domain, 25 Appraisal J. 421, 425 (1957). While such an opinion would appear reasonable, it does not necessarily exclude the "subconscious" inclusion of incidental losses into the valuation of even biased appraisers. Nor is it necessarily true that government appraisers are predominantly biased in favor of the condemnor; that governmental appraisals are invariably lower than those made by condemnees could indicate excess enthusiasm on the part of appraisers for condemnees as much as sympathy toward the condemnors' position on the part of governmental appraisers. 
practice of ignoring or creating exceptions to the basic market standard all argue persuasively for evaluation reform. But the changing emphasis of present-day takings amplifies the equitable and legal necessity for a revised standard of compensation. Today, private property is taken largely for the purpose of redeveloping the nation, as distinguished from the former aim of development. Conditions which are present today but were absent formerly should, therefore, influence the values upon which compensation concepts are based.

Historically, denial of incidental losses in eminent domain was understandable, if not justifiable. National development necessitated a liberal application of the public use concept. ${ }^{128}$ And since extensive and concentrated taking of improved property did not accompany this development, no corresponding liberality of compensation was essential; injustices were few and of a relatively minor nature. In recent years, however, the scope of taking has been greatly extended, and the damage incurred by the individual condemnee has concomitantly increased. In Berman v. Parker, the Supreme Court sanctioned a broad interpretation of the public use qualification of the Fifth Amendment: government may condemn private property simply to improve the aesthetic appearance of a community. ${ }^{129}$ Moreover, takings presently effected under this expanded public use doctrine generally involve concentrated and contiguous urban areas and result in magnified incidental damages. These changing circumstances accentuate the deficiencies in condemnation compensation and militate in favor of effecting a more equitable balance between the principles of public improvement and private indemnity.

Legal analysis should lead to a similar conclusion. Although the extent to which a governmental unit may interfere with private rights is broad, significant limits exist. In the closely related field of zoning restrictions, limitations are imposed on the degree of damage which the community in pursuit of the general good may inflict upon the individual. ${ }^{130}$ The right of government to regulate use of private property through zoning ordinances has long been upheld. ${ }^{131}$ When a state or any of its subdivisions seeks to develop a

128. See notes 35,36 supra and accompanying text.

129. "We do not sit to determine whether a particular housing project is or is not desirable. The concept of the public welfare is broad and inclusive . . . The values it represents are spiritual as well as physical, aesthetic as well as monetary. It is within the power of the legislature to determine that the community should be beautiful as well as healthy, spacious as well as clean, well-balanced as well as carefully patrolled. In the present case the Congress and its authorized agencies have made determinations that take into account a wide variety of values. It is not for us to reappraise them. If those who govern the District of Columbia decide that the Nation's Capital should be beautiful as well as sanitary, there is nothing in the Fifth Amendment that stands in the way." 348 U.S. 26,33 (1954).

130. See, generally, Norton, Elimination of Incompatible Uses and Structures, 20 Law \& Conterrp. Prob. 305 (1955); Note, 35 VA. L. Rev. 348 (1949). See also notes 131-34 infra and accompanying text.

131. The leading case upholding the constitutionality of zoning regulations under the police power is Village of Euclid v. Ambler Realty Co., 272 U.S. 365 (1926). There 
rationally planned city or town, the courts have asserted that the exercise of this power is not in conflict with constitutional provisions protecting private property; under state police power, governments may zone in futuro. ${ }^{132}$ However, retrospective zoning is generally prohibited since harm to the individual is thought to outweigh benefit to the community. ${ }^{133}$ Zoning in futuro restricts the indi-

Justice Sutherland considered the restriction against constructing a particular kind of building in a particular area to be a reasonable method of preventing nuisance. Therefore, due process was not violated.

132. "During the preparatory work for the zoning of Greater New York fears were constantly expressed by property owners that existing nonconforming buildings would be ousted. The demand was general that this should not be done. The Zoning Commission went as far as it could to explain that existing nonconforming uses could continue, but zoning looked to the future, and that if orderliness could be brought about in the future, the nonconforming building would to a considerable extent be changed by natural causes as time went on." BAsSETT, ZoNing 113 (2d ed. 1940).

A few state enabling acts require, and almost all zoning ordinances permit, nonconforming structures and uses to continue. See Norton, stura note 130, at 308; Note, Nonconforming Uses, 102 U. PA. L. REv. 91, 93 \& n.14 (1953). However, the alteration or enlargement of such structures is generally limited and their reconstruction after abandonment, discontinuance or destruction by act of God is prohibited. Ibid. Despite the broad language of the Court in Hadacheck v. Sebastian, 239 U.S. 394, 410 (1915), which would appear to sanction the use of zoning laws to restrict the continuance of existing uses, few state courts have sustained such a broad use of zoning powers. Bane v. Pontiac, 72 N.W.2d 134 (Mich. 1955) ; Application of Rogers, 208 Misc. 785, 144 N.Y.S.2d 869 (Sup. Ct. 1955) ; Curtis v. Cleveland, 130 N.E.2d 342 (Ohio Ct. App. 1955); James v. Greenville, 88 S.E.2d 661 (S.C. 1955). See also People v. Miller, 304 N.Y. 105,106 N.E.2d 34 (1952). A few states have permitted retrospective zoning; even in these states, a minimum time before terminating the nonconforming use is allowed. See State ex rel. Dema Realty Co. v. McDonald, 168 La. 172,121 So. 613, cert. denied, 280 U.S. 556 (1929) ; Standard Oil Co. v. Tallahassee, 183 F.2d 410 (5th Cir.), cert. denicd, 340 U.S. 892 (1950) ; Livingston Rock and Gravel Co. v. Los Angeles, 43 Cal. 2d 121, 272 P.2d 4 (1954). See Norton, supra note 130, at 308-11.

133. See People v. Miller, 304 N.Y. 105, 107-08, 106 N.E.2d 34, 35 (1952), where Fuld, J., stated: "It is the law of this state that nonconforming uses or structures, in existence when a zoning ordinance is enacted, are, as a general rule, constitutionally protected and will be permitted to continue, notwithstanding the contrary provisions of the ordinance. [cases cited] ... The decisions are sometimes put on the ground that the owner has secured a 'vested right' in the particular use-which is but another way of saying that the property interest affected by the particular ordinance is too substantial to justify its deprivation in light of the objectives to be achieved by enforcement of the provision. (Cf. Note, 41 Harv. L. Rev. 667; Note, 39 Yale L.J. 735, 740.) Every zoning regulation, because it affects property already owned by individuals at the time of its enactment, effects some curtailment of 'vested' rights, either by restricting prospective uses or by prohibiting the continuation of existing uses. A regulation of the latter variety, however, almost always imposes substantial loss and hardship upon the individual property owner-a loss much greater than that sustained by reason of a prospective use restriction only-and that factor underlies the rule that we are discussing. The destruction of substantial businesses or structures developed or built prior to the adoption of a zoning ordinance is not deemed to be balanced or justified by the advantage to the public, in terms of more complete and effective zoning, accruing from the cessation of such uses."

The court went on, however, to find the harboring of pigeons as a hobby to be an inconsequential use and not a "vested right." Id. at 109, 106 N.E.2d at 35. 
vidual's power to use, but does not destroy existing uses of, his property. One can reasonably be expected to conform to the zoning code and usually will not suffer severe out-of-pocket losses. In contrast, retrospective zoning may involve the destruction of a use of property which the owner has expended substantial sums to establish, and hence cause great loss. This distinction in zoning regulation parallels the differentiation between development and redevelopment-the taking of unimproved as contrasted with improved landsin eminent domain. Because of the very nature of these two governmental activities, that which in zoning limits the power of the government to actthe injury, incidental as well direct, to the property owner-in eminent domain should determine the compensation to be fixed.

Urban renewal, which has brought about an extremely large percentage of modern day takings and which is the redevelopment program most in the public eye, warrants special consideration. ${ }^{134}$ These governmental projects are designed to redevelop municipalities, both socially and economically, by encouraging private capital to replace slums and other retarded areas with modern residential and commercial facilities. ${ }^{\mathbf{1 3 5}}$ Of vital importance to the economic

134. Under the Urban Renewal Program, the federal government assumes at least two thirds of the cost difference between condemnation plus land clearing expenses and the price paid by developers for the cleared property. Local governments pay the remainder. See Housing Act, 1949, $\$ 104,63$ Stat. 416, as amended by Housing Act, 1956, § 306, 70 STAT. 1101, 42 U.S.C. $\$ 1454$ (Supp. IV, 1957). For the impact of this program on the nation, see notes 9-12 supra. Since 1949, Congress has authorized one and one quarter billion dollars for slum clearance and urban renewal. See Can the Big Cities Come Back?, U.S. News and World Report, July 19, 1957, pp. 72-73.

135. The taking of property for this purpose was given constitutional sanction in Berman v. Parker, 348 U.S. 26 (1954). This case overruled a district court decision that had declared the taking of commercial, non-slum property for the development of commercial and residential structures not a "public use" and not in the scope of the Redevelopment Act. Schneider v. District of Columbia, 117 F. Supp. 705 (D.D.C. 1953). While sustaining the constitutionality of the act, the district court gave it a restricted interpretation which was replaced by the exceedingly broad interpretation of the Supreme Court.

Most states have sanctioned use of eminent domain against other than slum areas for the purpose of redevelopment. See, e.g., Despatcher's Cafe, Inc. v. Somerville Housing Authority, 332 Mass. 259, 124 N.E.2d 528 (1955) ; Kansas ex rel. Fatzer v. Urban Renewal Agency, 179 Kan. 435, 296 P.2d 656 (1956); Bristol Redevelopment and Housing Authority v. Denton, 198 Va. 171, 93 S.E.2d 288 (1956). See compilation indicating states upholding the constitutionality of such takings. URBAN RENEWAL BRANCH, DIvision of Law, Housing \& Home Finance Agency, Citations to Basic Enabling Legislation and Selected Cases on Urban Redevelopuent and Urban Renewal (Sept. 1, 1956).

Three states have declared that takings of non-slum commercial property for commercial purposes is in violation of their state constitutions. See Adams v. Housing Authority, 60 So. 2d 663 (Fla. 1952) ; Housing Authority v. Johnson, 209 Ga. 560, 74 S.E.2d 891 (1953); Edens v. Columbia, 228 S.C. 563, 91 S.E.2d 280 (1956).

The courts that have upheld urban renewal legislation have done so mainly on the ground that the program, by removing slums, improves the health and safety of the community. Increasing emphasis upon commercial and industrial re-use presents doubts as to whether redevelopment agencies envision the same primary purpose for the program. See Sullivan, Adninistrative Procedure and the Advocatory Process in Urban Rede- 
health of cities and the welfare of their residents, ${ }^{136}$ urban renewal programs may be severely impeded by the denial of important condemnation damages. For this denial has marshalled strong pressure groups to oppose such programs by political as well as judicial means. ${ }^{137}$ And the antagonism of these groups has been augmented by the discriminatory nature of these programs.

Urban renewal projects favor particular private enterprises at the expense of less modern and less highly developed businesses. ${ }^{138}$ Under these programs, business property and residences may be taken through eminent domain although their physical condition would not justify governmental condemnation of the property by exercise of police power. ${ }^{139}$ Because private developers

velopment, 45 CALIF. L. REv. 134, $138 \mathrm{n} .19$ (1957). Of the 234 project areas approved for final planning or execution as of Dec. $31,1956,76$ were to be devoted either exclusively or predominantly to commercial or industrial use. The secondary use of these 234 projects was listed as either commercial or industrial in 165 projects. Housung and Home Finance Agency, Urban Renewal Administration, Urban Renewal Project Characteristics 10 (1956). For an account of the commercial and industrial importance of urban renewal projects, see Industrial Lure Songht in Title I, N.Y. Times, Aug. 18, 1957, § 8, p. 1, col. 1 .

136. See Grutzner, Cities and Suburbs in Race Against Spreading Slums, N.Y. Times, Jan. 31, 1957, p. 16, col. 1. There, Federal Housing Administrator Albert Cole warned that unless most American cities undertake urban renewal programs by 1960 they are destined for "municipal" ruin by 1965 . See, generally, The Future of Cities and URBan RedeVELOPMENT (Woodbury ed. 1953).

137. See note 13 supra.

138. See, e.g., writ, summons and complaint issued Sept. 10,1957, by the Superior Court for Connecticut, County of New Haven, against the members of the New Haven Redevelopment Agency and the City of New Haven, wherein a businessman condemnee alleges that the redevelopment agency had sold the private redeveloper "sufficient firstclass commercial property in the heart of the New Haven business district so that he [the redeveloper] may make a large profit in developing it."

139. The police power is regulatory and as such is distinct from eminent domain which is the power to take property. 1 Niczors 66 . The power of eminent domain is applied by the public and upheld by the courts because the use and enjoyment of such property is beneficial to the public. The restrictions on property imposed by the police power are designed to prevent injury to the public. While the distinction is mainly one of degree, the police power is used to destroy objectionable property rather than transform it to the use and enjoyment of the public. Id. at 69-70.

For a strong dissent on the application of the power of eminent domain in urban renewal, see Prettyman, J., in Schneider v. District of Columbia, 117 F. Supp. 705, 719 (D.D.C. 1953): "The hypothesis . . . is an urban area which does not breed disease or crime, is not a slum. Its fault is that it fails to meet what are called modern standards. Let us suppose that it is backward, stagnant, not properly laid out, economically Eighteenth Century-anything except detrimental to health, safety or morals. Suppose its owners and occupants like it that way. Suppose they are old-fashioned, prefer single-family dwellings, like small flower gardens, believe that a plot of ground is the place to rear children, prefer fresh to conditioned air, sun to fluorescent light. In many circles all such views are considered 'backward and stagnant.' Are those who hold them therefore blighted? Can they not, nevertheless, own property? Choice of antiques is a right of property. Or suppose these people own these homes and can afford none more modern. The poor are entitled to own what they can afford. The slow, the old, the small in ambition, the 
can secure valuable sites at prices well below their true worth, ${ }^{140}$ they in effect are subsidized by governments at the expense of other private property owners. So viewed, the denial of incidental losses imposes on condemnees a greater burden of financing public improvements; condemned businesses are thus forced to contribute to the pecuniary success of other profit-making enterprises. ${ }^{141}$ True, such condemnations are primarily for public uses. ${ }^{142}$ But even assuming that nonpayment of incidental losses is a benefit of condemnation which should inure to the government, profit-making corporations should not necessarily receive such preferential treatment.

devotee of the outmoded have no less right to property than have the quick, the young, the aggressive, and the modernistic or futuristic.

"Is a modern apartment house a better breeder of men than is the detached or row house? Is the local corner grocer a less desirable community asset than the absentee stockholder in the national chain or the wage-paid manager? Are such questions as these to be decided by the Government? And, if the decisions be adverse to the erstwhile owners and occupants, is their entire right to own property thereby destroyed? Even if the line between regulation and seizure, between the power to regulate and the power to seize, is not always etched deeply, it is there. And, even if we progress in our concepts of the 'general welfare,' we are not at liberty to obliterate the boundary of governmental power fixed by the Constitution."

140. The price developers pay for this cleared property is usually, dollar-wise, considerably below that which they would have to pay for similar property in the absence of the program. However, the number of building restrictions imposed by local renewal authorities, such as space coverage and limitations in height, sharply reduce the apparent cost advantage. Nonetheless, because of (1) favorable finance arrangements and interest rates available under the program, (2) the ability to obtain choice and large tracts of land that could otherwise not be obtained and (3) the probability that in the long run the building restrictions imposed upon developers will not be to their disadvantage, the program offers profitable financial opportunities for those in a position to invest. Admittedly, the program has yet to prove itself as a profitable venture, mainly because it is still quite new, but there is little reason to believe it will prove unprofitable. Interview, May 3, 1957, with James H. Scheuer, Chairman, Executive Committee, City and Suburban Homes Co., New York, N.Y.

141. By their nature, urban renewal programs entail heavy financial outlays for those who seek to take advantage of them. Only highly successful enterprises can afford to invest these huge amounts of capital, and consequently the number of redevelopers in this field is, in practice, restricted. Rarely will a condemnee be in a position to invest in these programs so as to insure his interests in the condemned property. Cf. Sullivan, supra note 135 , at $139-41$.

142. If, however, groups with the power of condemnation which were not agencies of the government sought to condemn private commercial property for the use of private enterprise in this manner, the courts would probably prevent their so doing. The indirect benefit to the public might possibly induce some courts to sanction such action, but they would most likely have to be convinced that the only alternative was economic ruin to the community. See 2 Nichors 479-81, 560. See also People v. Salem, 20 Mich. 452 (1870) ; Lowell v. Boston, 111 Mass. 454, 461 (1873): "The promotion of the interests of individuals, either in respect of property or business, although it may result incidentally in the advancement of the public welfare, is, in its essential character, a private and not a public object. However certain and great the resulting good to the general public, it does not, by reason of its comparative importance, cease to be incidental. The incidental advantage to the public, or to the State, which results from the promotion of private 
A comparison of judicial reaction to profit-making corporations enjoying the power of eminent domain with the treatment given the government condemnor suggests that the restricted concept of property which diminishes government liability may not extend to other condemnors. ${ }^{143}$ Initially, the scope of a taking may be differently defined when the claim is made against a private corporation instead of the government. Railroads with the power of condemnation have been held to have taken private property when smoke from their engines caused damage to abutting homes; ${ }^{\mathbf{1 4 4}}$ if a similar claim were made against the government, it would, absent statute, have been dismissed as dannum absque injuria. ${ }^{145}$ In addition, two Supreme Court decisions

interests, and the prosperity of private enterprises or business, does not justify their aid by the use of public money raised by taxation, or for which taxation may become necessary."

In cases where the question of "public use" is a close one, as it is under these conditions, the courts tend to be more liberal if the government rather than a private corporation with the power of condemnation exercises such a right. See, e.g., Talbot v. Hudson, 82 Mass. (16 Gray) 417 (1860). See also 2 NICHols 480-81.

143. Governmental liability is also dependent upon the purpose for which the condemnation is made. The restricted concept of liability is often limited, even in eminent domain, to situations in which the governmental authority acts in a governmental capacity. Proprietary activity is often not shielded by the usual governmental immunities. For example, where a municipality condemned a public street in order to build a garage and bus depot in connection with its transit system-a proprietary activity- the city was required to pay for the cost of moving and relocating the public utility equipment which was beneath the surface of the street. The New York court observed that the common law requires a utility company to bear the risk of relocating its equipment due to regulation, control, improvement or extention of the street and highway systems. But it went on to state: "This common law rule, however, does not go so far as to place the cost of removal and relocation upon the company, when the change is required in behalf of other public service corporations or in behalf of municipalities excrcising a proprictary instead of a governmental function. The departure from the rule arises out of the distinction between public welfare and private enterprise of a quasi public nature." In re Gillen Place, 195 Misc. 685, 688, 90 N.Y.S.2d 641, 643-44 (Sup. Ct. 1949). This case exemplifies the judicial pattern of limiting governmental immunities in condemnation-distinguishing between "public welfare and private enterprise of a quasi public nature." See notes 144-149 infra and accompanying text.

144. See Richards v. Washington Terminal Co., 233 U.S. 546, 557 (1914). See also Lenhoff, Development of the Concept of Eminent Domain, 42 CoLun. L. Rev. 596, 610-11 (1942), wherein the author points out that in jurisdictions in which damage was not considered a taking, railroads were held to have "taken" property by damaging abutting homes: "Thus, a new action viewed 'in light of the Fifth Amendment' was substituted for the common law action for injuries caused by other than physical invasion."

145. See Lenhoff, supra note 144, at 608 \& n.65, 609. Today, however, such damages might be considered a taking under Fifth Amendment rationale. See United States v. Causby, 328 U.S. 256, 261 (1946). But cf. Ewalt v. Pennsylvania Turnpike Comm'n, 382 $\mathrm{Pa}$. 529, 533-34, 115 A.2d 729, 731 (1955), where the court stated that although debris from road construction injured plaintiff's property there was no taking, and damages were merely consequential. Significantly, the court, by not deciding the issue on an eminent domain rationale, succeeded in preventing the Turnpike Commission, a "private enterprise of a quasi public nature," from avoiding liability by imputing governmental immunity to itself. Instead, by declaring the damage caused by trespass not eminent domain, the court held the Commission liable. This action seems to be another judicial effort to restrict the scope of governmental immunity in eminent domain. 
indicate that the measure of damages differs if condemnation is effected by the government rather than a profit-making corporation. In Grand River Dam Authority v. Grand-Hydro, the condemnor, a private power company with the right of condemnation, was licensed under the Federal Power Act to use a river bordering the condemned property for hydroelectric purposes. ${ }^{146} \mathrm{Al}-$ though the condemnee was never able to use the site as a power source, it was compensated for loss of this potential use; the Court argued that the fair market value of the property was enhanced by its additional value as the potential site of a hydroelectric plant. 147 The Court raised, but did not answer, the question whether potential use would be included in the market value if the government, rather than a private corporation, was the condemnor. ${ }^{148}$ This question was effectively answered in 1956 in United States $v$. Trein City Power Co. ${ }^{149}$ Under an analogous set of facts, the federal government was the condemnor, and the Court, in contrast, held that the potential value of the condemned property as a power site could not be included in the market value. The holdings in these cases conform to the policy existing in England. There, special factors excluded from market value if the government is condemnor are included when the condemnation is effected by a private corporation. ${ }^{150}$

Such a distinction has been urged on the ground that lower compensation awards in government takings benefit the taxpayer, but in condemnations by private corporations, any benefit will accrue to private enterprise. ${ }^{151}$ This argument overlooks the probability of a private corporation's passing the increased condemnation costs on to its taxpaying customers. ${ }^{152}$ Accordingly, any variance in determining compensation would appear to derive from profitmaking considerations inherent in the taking. A profit-making corporation's gain in obtaining property through eminent domain should be borne equally by the public which benefits from the condemnation, not inordinately by the

146. 335 U.S. 359 (1948).

147. In contrast to the general rule, the measure of damages was determined by its value to the taker. See id. at 367 .

148. Id. at 373 .

149. 350 U.S. 222 (1956). See Comment, 24 U. CHI. L. Rev. 370 (1957); Note, 25 Gro. Wash. L. Rev. 450 (1957).

150. $9 \& 10$ Geo. 5, c. 57, $\$ 2(3)$ (1919): "The special suitability or adaptability of the land for any purpose shall not be taken into account if that purpose is a purpose to which it could be applied only in pursuance of statutory powers, or for which there is no market apart from special needs of a particular purchaser or the requirements of any Government Department or any local or public authority . . .."

This statute applies only to condemnations by governmental agencies. Privately owned corporations with the power of condemnation must pay for "special value." See McCormICK 524,526 n.24.

151. See Gilmore v. Central Maine Power Co., 127 Me. 522, 145 Atl. 137 (1929), where this argument apparently was raised; 1 ORGEL $\$ 93$.

152. The court in Gilmore v. Central Maine Power Co., supra note 151, pointed out that whatever increase in cost the private condemnor had to pay to compensate the condemnee would be passed on to the general public through rate increases. See Note, 65 Y ALE L.J. 96, 103 (1955) ; cf. MCCORMICK 524, 526 \& n.24. 
owners of the condemned property. Thus, any condemnation, like urban renewal, which directly and significantly aids private profit-making enterprises should not be accorded special benefits which might inure, justifiably or not, to government under eminent domain. Admittedly, the threat to property rights latent in urban renewal-resulting from an almost unlimited public use concept combined with preferential treatment within the business community - cannot be curbed solely by adopting a more flexible standard of compensation. ${ }^{153}$ Such a standard will, however, make the program more compatible with prevailing notions of justice.

\section{ConcLusion}

At a minimum, compensation should be awarded for incidental losses sustained in urban renewal programs or in any other takings which redound to the direct benefit of profit-making corporations. Recovery should not, however, be confined to claims arising in this context. Ultimately, the public which benefits from improvements should bear the incidental losses occasioned by any condemnation for which just compensation is required; no reason appears for placing an inordinate burden on the individuals whose property is appropriated for the public benefit. Separate appraisal of incidental losses would also make the basic market valuation a more operable standard. Manipulation of that formula to include such losses would no longer be necessary ;154 thus the objectivity originally justifying its use would be restored. While full compensation for incidental losses may result in greater condemnation expenses, the increase need not be material. The additional payments may in fact be largely included within present awards. Reform might be initiated either by courts or by legislatures. The courts have been responsible for much of the existing relaxation of the market value standard and have stated that matters of just compensation are judicial problems. ${ }^{155}$ But legislative

153. See Note, 68 Harv. L. REv. 1423, 1427-28 (1955) (compensation alone will not insure the necessary protection to condemnee's if private enterprise has an interest in the condemnation proceedings).

154. After commenting about the fact that some appraisers "subconsciously" allow for incidental damages, one appraiser indicated the probable effect of the 1952 federal act allowing moving costs in defense projects: "While no actual cases of such influences [subconscious inclusion] have been documented or are known to exist, suffice to say that henceforth defense projects, large and small alike, will be removed from the pale of such influences, objective or subjective. All will know and be ever mindful that by the payment of his expenses in moving a fair and specific contribution is being effected towards making the seller truly 'whole.' " Pearl, Appraiser's Guide Under Law Allowing Moving Costs, 21 Appratsal J. 327, 330 (1953).

155. See Monongahela Nav. Co. v. United States, 148 U.S. 312, 327 (1893) ("The legislature may determine what private property is needed for public purposes-that is a question of political and legislative character; but when the taking has been ordered, then the question of compensation is judicial. It does not rest with the public taking the property, through Congress or the legislature, its representative, to say what compensation shall be paid, or even what shall be the rule of compensation."); Dore v. United States, 119 Ct. Cl. 560, 581-83, 97 F. Supp. 239, 242-44 (1951). See also 1 Nicrols 347; 3 NICHOLS 157. 
action would not be unprecedented, ${ }^{156}$ and through this source, reform might be effected more fully and expeditiously. ${ }^{157}$ In the final analysis, however, the source of reform is not important-the fact of reform is.

156. Legislative precedent for granting incidental losses can be found in the water supply statutes, see note 111 supra, moving costs in urban renewal and defense projects and similar state action, see note 115 supra. The legislatures have, however, been reluctant to change the present policy. See, e.g., \&S Cong. REC. 1649, 1650, 1653, 1654, 1656 (1942), where a proposed amendment to award proximate losses in addition to fair market value was defeated. The tenor of the debates reflected a feeling on the part of Congress that the Supreme Court's position on just compensation is a firmly entrenched doctrine which the legislature, at least during a wartime period, should not upset. The debate over this measure also indicated concern over the speculative nature of incidental or "proximate" losses. But this latter argument is of a different kind from the rationale the Supreme Court used to support the restricted meaning of just compensation, i.e., the limited scope of property rights. Cf. the remarks of Federal Housing Commissioner Albert Cole questioning whether Congress could constitutionally compensate for good will. Hearings Before the House Committee on Banking and Currency on H.R. 10157, 84th Cong., 2d Sess. 69 (1956). But see note 114 supra and accompanying text. See also Massachusetts Rcport 12-13. A majority of the Commission decided against allowing compensation for lost profits resulting from condemnation, holding that such action would be "opening the door to speculative damages." But see note 48 supra and accompanying text.

157. The mechanics for compensating for incidental losses could, for the most part, coincide with the present state and federal procedures for ascertaining market value. The courts in England and the American courts on the various occasions cited in text have worked out methods for determining these losses within the existing procedural framework. When governmental units contemplate programs such as urban renewal projects or extensive road construction, however, which require concentrated and numerous takings, it might be more feasible to make provision for special commissions. 